\title{
The Legality of Automatic Fund Transfer Plans
}

On November 1, 1978, the Board of Governors of the Federal Reserve System and the Board of Directors of the Federal Deposit Insurance Corporation rescinded the regulatory ban against automatic fund transfer plans, ${ }^{1}$ commonly called AFTs. Under these plans, a bank depositor opens two accounts: a savings account and a checking account. The depositor maintains a low balance in the checking account and the bank automatically transfers funds from the savings account to the checking account to cover the checks drawn against it. AFTs enable depositors to spend interest-earning funds in savings accounts by writing checks, and thus resemble interest-paying checking accounts.

Fifteen days after the Federal Reserve Board announced its rescission of the ban against AFTs, a group of savings and loan associations brought suit in federal court seeking to restrain the agencies from implementing the rescission. ${ }^{2}$ The plaintiff organization challenged the rescission as violating two distinct statutory provisions: ${ }^{3}$ the 1933 prohibition of interest payments on demand deposits $^{4}$ and a 1973 prohibition of so-called NOW accounts. ${ }^{5}$

The district court held that neither statute prohibited AFTs, ${ }^{6}$

143 Fed. Reg. 20,001, 20,222 (1978) (amending 12 C.F.R. $\S \S 217.5(c)(2), 329.5(c)(2)$ (1978)), reprinted in [1978-1979 Transfer Binder] Fed. Banking L. REP. (CCH) II 97,432, 97,437 .

2 See [1978-1979 Transfer Binder] Fed. Banking L. Rep. (CCH) \ 97,455.

${ }^{3}$ Consolidated Points and Authorities in Opposition to Defendants' Alternative Motions to Dismiss or for Summary Judgment and in Support of Plaintiff's Cross-Motion for Summary Judgment at 22-23, United States League of Sav. Ass'ns v. Board of Governors of the Fed. Reserve Sys., 463 F. Supp. 342 (D.D.C. 1978) [hereinafter cited as Consolidated Points and Authorities].

+12 U.S.C. $\$ 371$ a (1976) (originally enacted as Banking Act of 1933, Pub. L. No. 73-66, $\S 11$ (b), 48 Stat. 181 (amending Federal Reserve Act, Pub. L. No. 63-43, § 19, 38 Stat. 270 (1913)).

512 U.S.C. $\$ 1832$ (a) (1976) (originally enacted as Act of Aug. 16, 1973, Pub. L. No. 93 100, § 2(a), 87 Stat. 342). NOW accounts, in contrast to AFTs, consist of only one account: an interest-bearing savings account. Depositors may draw check-like "negotiable orders of withdrawal" against the account, and thus use NOW accounts as they might use checking accounts. For a more detailed discussion of NOW accounts, see text and notes at notes 115126 infra.

- United States League of Sav. Ass'ns v. Board of Governors of the Fed. Reserve Sys., 463 F. Supp. 342, 352 (D.D.C. 1978), vacated sub nom. American Bankers Ass'n v. Connell, 595 F.2d 887 (D.C. Cir. 1979), cert. denied, 48 U.S.L.W. 3258 (U.S. Oct. 15, 1979). The court reasoned that the interest paid under AFTs is paid on money in savings deposits rather than demand deposits, and so the plans did not vialate the 1933 prohibition of interest payments on demand deposits. See id. at 350 . The court decided that the NOW account legislation, restricting withdrawals from interest-bearing accounts by negotiable instruments, did not 
but the Court of Appeals for the District of Columbia Circuit reversed, holding that AFTs violated the spirit, if not the letter, of both the 1933 and the 1973 provisions. ${ }^{7}$ The court set aside the rescission of the AFT ban, ${ }^{8}$ but postponed the effectiveness of its judgment until January 1, 1980, recognizing that financial institutions had spent large sums on introducing $\mathrm{AFTs}^{9}$ and "in the expectation that the Congress will declare its will upon these matters." 10 Unfortunately, the House and Senate have been unable to agree on the proper scope of remedial action, ${ }^{11}$ and the compromise

reach AFTs, apparently because AFT checks are not drawn against the interest-bearing savings account itself. Id. at 351 .

7 The court reached its conclusion with little analysis, merely citing the pertinent regulations and asserting that AFTs violated them. American Bankers Ass'n v. Connell, No. 781337, slip op. at 2, 4 n.1 (D.C. Cir. Apr. 20, 1979) (unpublished order with explanatory memorandum, dispostion reported at 595 F.2d 887 (D.C. Cir. 1979)) (setting aside 12 C.F.R. $\S \S 217.5(\mathrm{c})(2)-(3), 329.5(\mathrm{c})(2), 545.4-2,701.34$ (1978)), cert. denied, 48 U.S.L.W. 3258 (U.S. Oct. 15, 1979).

${ }^{8}$ American Bankers Ass'n v. Connell, No. 78-1337, slip op. at 3-4 (D.C. Cir. Apr. 20, 1979), cert. denied, 48 U.S.L.W. 3258 (U.S. Oct. 15, 1979).

- The court indicated that "enormous investments hàve been made by various financial institutions" in introducing the accounts, that "methods of financial operation in the nation have rapidly grown to rely on much of this," and that "a disruption of the offered services would necessarily have a deleterious impact on the financial community as a whole, in the absence of the certainty that new procedures are authorized for the foreseeable future." Id. at 3.

${ }^{10} \mathrm{Id}$. at 4 . The court of appeals ruled that two additional regulations be set aside: a Federal Home Loan Bank Board regulation, 12 C.F.R. $\S 545.4-2$ (1978), permitting federal savings and loan associations to enable depositors to withdraw funds from savings accounts through the use of off-premises machines called remote service units (RSUs), and a National Credit Union Administration regulation, id. § 701.34, permitting members of credit unions to draw share drafts, the practical equivalent of checks, against their interest-bearing creditunion share accounts. American Bankers Ass'n v. Connell, No. 78-1337, slip op, at 4 (D.C. Cir. Apr. 20, 1979), cert. denied, 48 U.S.L.W. 3258 (U.S. Oct. 15, 1979). The court asserted that these services violated federal law, citing 12 U.S.C. $\$ \S 1464(b)(1), 1751-1790$ (1976), but postponed the effectiveness of its judgment as to them as well.

"The controversy concerns the extent to which the AFT-enabling legislation should serve as a penetrating reform of the regulation of financial institutions. On September 11, 1979, the House passed the Consumer Checking Account Equity Act of 1979, 125 Cong. REc. H7651 (daily ed. Sept. 11, 1979). The bill contained provisions narrowly designed to exempt AFTs from the 1933 prohibition and weaken the restrictions of the 1973 NOW account prohi-

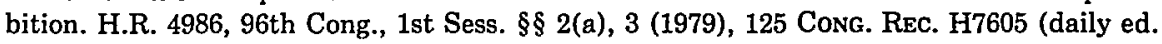
Sept. 10, 1979).

The Senate passed its version of the bill on November 1, 1979, 125 ConG. Rec. S15690 (daily ed. Nov. 1, 1979). The Senate bill, the Depository Institutions Deregulation Act of 1979, H.R. 4986, 96th Cong., 1st Sess. (1979) (as amended by Senate), 125 Cong. REc. S14926 (daily ed. Oct. 23, 1979), in addition to exempting AFTs from the 1933 prohibition, would have repealed the 1973 NOW account prohibition altogether, id. § 110(c), 125 CoNG. REc. at S14928. It also would have mandated the gradual elimination of the federal control of interest rates on savings and time deposits that has been a fixture of banking regulation since the depression, id. $\S \S 107-110$ (a), 125 CoNG. REc. at $S 14928$, see text and notes at notes $30-44$ infra. And finally, the Senate version would have eliminated, effective January 1, 1990, the statutory differential between maximum interest rates allowed at commercial banks and 
legislation finally enacted in the closing days of last term ${ }^{12}$ had only temporary effect. The new legislation permits commercial banks to offer AFTs, but only until March 31, 1980,13 by which time the legislators expect to have decided on a permanent resolution of the AFT controversy. ${ }^{14}$

This comment examines the legality of AFTs under the statutory and regulatory framework in which they developed. After analyzing the economic background and regulatory history of the 1933 prohibition of interest payments on demand deposits, the comment concludes that AFT plans are entirely consistent with the original congressional purposes behind that legislation. The comment then examines the 1973 NOW account prohibition in the context of the policy considerations leading to its enactment, and concludes that AFT plans are not comprehended by the later provision either. Accordingly, the statutes and regulations involved should properly be viewed as already permitting AFT plans, thus requiring no further congressional action for their continued use.

\section{Deposits "Payable on Demand"-Section 371a}

Section 371a of Title 12 of the United States Code provides in pertinent part that "[n]o member bank [of the Federal Reserve System] shall, directly or indirectly, by any device whatsoever, pay any interest on any deposit which is payable on demand."15 It is often assumed that a deposit payable on demand, or "demand deposit," is the same thing as a checking account and that the distinc-

those allowed at thrift institutions. H.R. 4986, 96th Cong., 1st Sess. $§ 110$ (b) (1979) (as amended by Senate), 125 CoNG. REc. S14928 (daily ed. Oct. 23, 1979); see text and note at note 132 infra.

12 Act of Dec. 28, 1979, Pub. L. No. 96-161, § 101, 93 Stat. 1233.

is $I d . \S 104,93$ Stat. 1234 . The measure also extends the same type of temporary authorization for federal savings and loan associations to offer RSUs, id. § 102, 93 Stat. 1233, and for federal credit unions to offer share draft accounts, id. $\S 103,93$ Stat. 1234. Additionally, the Act temporarily overrides state constitutional and statutory provisions containing usury ceilings on certain loans, $i d . \S 105,93$ Stat. 1234, and authorizes depository institutions in New Jersey to offer NOW accounts, $i d$. $\S 106,93$ Stat. 1235; see text and notes at notes 115126 infra.

"See, e.g., 125 Cong. Rec. S19164 (daily ed. Dec. 19, 1979) (remarks of Sen. Proxmire) ("Passage of this legislation will allow the process to proceed and allow the conferees to resolve differences on H.R. 4986 by March 31, 1980.").

1512 U.S.C. \$ 371a (1976). Section 371a applies to federally chartered banks or statèchartered banks that are members of the Federal Reserve System. Federal laws governing "insured nonmember banks"- state banks insured by the Federal Deposit Insurance Corporation (FDIC)-are substantially parallel to, although in most cases separate from, the laws governing "member banks." For the sake of brevity, however, this comment will refer to section $371 \mathrm{la}$ as governing both member and nonmember insured banks. See generally Scott, The Dual Banking System: A Model of Competition in Regulation, 30 StAN. L. Rev. 1 (1977). 
tive feature of a demand deposit is that funds it contains are dispensed by check. Thus it is commonly concluded that section $371 \mathrm{a}$ prohibits interest payments on any checking account. Current federal regulations, ${ }^{16}$ however, define a demand deposit independently of the instruments used to withdraw money from it. Under these regulatory definitions, all checking accounts are not necessarily demand deposits. Interest payments on those checking accounts not deemed demand deposits would not violate section 371a.

\section{A. The Current Regulatory Definitions}

Statutes currently in force do not define "demand deposits."17 Instead, Congress has granted the Federal Reserve Board the power to define demand deposits by regulation for the purposes of section 371a. ${ }^{18}$ The Reserve Board has promulgated its definition as part of Regulation $Q,{ }^{19}$ the body of federal regulations dealing generally with interest payments on deposits at member banks. ${ }^{20}$ The Federal Deposit Insurance Corporation (FDIC) has promulgated an identical definition as part of its regulations governing banks that are federally insured but not members of the Federal Reserve System. ${ }^{21}$ Under the regulatory schemes of both agencies, the definition of demand deposits depends on those of time and savings deposits; thus, one must first review the definitions of the latter types of accounts to determine what is meant by a demand deposit.

Although there are several types of time deposits and their precise definitions are rather involved, they all share a common characteristic: once a depositor opens a time-deposit account, he cannot gain access to the account without having provided thirtydays written notice to the bank. ${ }^{22}$ Savings deposits are defined

${ }^{16} 12$ C.F.R. $\$ \S 204.1(a), 217.1$ (a), 329.1(a) (1979).

"See 12 U.S.C. $\S 371$ a (1976). When Congress enacted section 371 a in 1933 , "demand deposit" was defined by statute. Federal Reserve Act, Pub. L. No. 63-43, § 19, 38 Stat. 270 (1913). See text and note at note 86 infra. In 1935, Congress rescinded the statutory definition and gave the Federal Reserve Board the authority to adopt its own definitions. Banking Act of 1935, Pub. L. No. 74-305, $\S 324(\mathrm{a}), 49$ Stat. 714 (amending Federal Reserve Act, Pub. L. No. $63-43, \S 19,38$ Stat. 270 (1913)) (current version at 12 U.S.C. $\S 461$ (a) (1976)).

is 12 U.S.C. \& 461(a) (1976).

1912 C.F.R. \& 217 (1979).

20 The Federal Reserve Board has promulgated deposit definitions nearly identical to those of Regulation $Q$ as part of Regulation $D$, the body of federal banking regulations governing reserve requirements for member banks. Id. $\S 204.1$.

${ }^{21}$ Id. $\S 329.1$.

${ }_{22}$ Time deposits are of two types: certificate of deposit and open account. Id. $\S \S 204.1$ (b), 217.1(b), 329.1(b). Certificates of deposit are evidenced by a written instrument (that may or may not be negotiable) stating that the amount of the deposit may be repaid only upon presentation of the instrument and upon either the expiration of a prescribed time period (not 
by two characteristics. First, only specified types of persons, such as individuals, certain not-for-profit corporations, and particular governmental units, may hold savings accounts. ${ }^{23}$ Second, the bank must reserve the right to require at least thirty-days notice of any withdrawal, ${ }^{24}$ but is not required to exercise that right.

A demand deposit is defined as any deposit other than a savings or time deposit. ${ }^{25}$ Thus, any deposit from which the bank does not restrict withdrawals in the stringent manner of time deposits, and for which the bank does not reserve an option to require thirty-days notice of withdrawal, is a demand deposit. It follows that any deposit held by an individual to which a bank attaches the right to require thirty-days notice of withdrawal is a savings deposit, and not a demand deposit-regardless of the instruments used to make withdrawals. Under these definitions, AFTs do not seem to violate section 371a's prohibition against the payment of interest on demand deposits. Although the bank automatically transfers funds from an interest-bearing savings account to a non-interest-bearing demand deposit, it reserves the right to require thirty-days notice before making such transfers. The account in which the funds are kept prior to transfer, the only account in the AFT plan on which interest is paid, is therefore not a demand deposit.

\section{B. The Historical Background of Section 371a}

The apparent legality of AFTs under the current regulatory definitions may, however, be inconsistent with the congressional purpose of section 371a. In enacting the prohibition, Congress may have intended to include all checking accounts in the words "any deposit which is payable on demand," notwithstanding modern agency regulation. If so, AFTs may still be illegal; although the interest-bearing account in the AFT is technically a savings account, the plan as a whole operates as a checking account and might be considered a device that indirectly pays interest on that checking account. Whether the bank-deposit definitions of Regulation $\mathbf{Q}$

less than thirty days), the arrival of a prescribed date (not less than thirty days after the funds are deposited), or upon thirty-days written notice to the bank. Id. $\S \S 204.1(\mathrm{c}), 217.1$ (c), 329.1(c). Open-account time deposits do not necessarily involve prescribed maturity dates or periods. If a maturity date is imposed, it must be not less than thirty days after the date of the deposit, and if no maturity date is imposed, the account may be closed or depleted only upon not less than thirty-days written notice. Id. $\$ \S 204.1$ (d), 217.1(d), 329.1(d).

${ }^{23}$ Id. $\$ \S 204.1(\mathrm{e})(1), 217.1(\mathrm{e})(1), 329.1(\mathrm{e})(1)$. For-profit corporations may hold savings accounts if the amount deposited does not exceed $\$ 150,000$. Id.

24 Id. §§ 204.1(e)(2), 217.1(e)(2), 329.1(e)(1)(iii).

${ }^{25}$ Id. $\$ \S 204.1(\mathrm{a}), 217.1(\mathrm{a}), 329.1(\mathrm{a})$. 
should be permitted to control the question of AFT legality under section 371a thus depends on whether the definitions are consistent with the purposes of the statute. ${ }^{28}$ The relevant historical background and legislative history of section $371 \mathrm{a}$ indicate that the current regulatory definitions are consistent with the underlying congressional purposes of the prohibition.

Congress enacted section 371a's prohibition of interest payments on demand deposits as part of the Banking Act of $1933,{ }^{27}$ also called the Glass-Steagall Act. The Act as a whole was designed to correct the weaknesses in American banking thought to have caused the banking crisis of 1933 and to some extent the stock market collapse of $1929 .{ }^{28}$ The bill was enacted in great haste and without formal hearings, ${ }^{29}$ leaving little legislative history. Given the

${ }^{26}$ The Regulation $Q$ demand-deposit definitional structure is composed of two regulations, $i d$. $\S \S 217.1,329.1$, promulgated by administrative agencies pursuant to express delegations of definitional authority by Congress, 12 U.S.C. $\$ \S 461 \mathrm{a}, 1828(\mathrm{~g})(1976)$, see text and note at note 100 infra. One respected authority maintains that under such circumstances the regulation is entitled to a high degree of deference; since Congress instructed the agencies to issue the definitional regulations, their promulgation is an exercise of legislative power. See K. Davis, Administrative Law Treatise $\$ 5.03$ (1958 \& Supp. 1970).

In Batterton v. Francis, 432 U.S. 416 (1977), the Supreme Court seemed to adopt Professor Davis's view. The Court declared that when Congress expressly delegated to the Secretary of Health, Education, and Welfare the power to define "unemployment" in a particular statutory provision (42 U.S.C. $\S 607$ (a) (1976)), 432 U.S. at 419 , the definitions adopted by the Secretary had "legislative effect." Id. at 425 . Accordingly, the Court decided that it could not invalidate the Secretary's definition "simply because [the Court] would have interpreted the statute in a different manner." Id. Yet the Court noted that agency definitions may be invalidated when the definitions bear "no relationship to any recognized concept" of the term or "would defeat the purpose" of the delegating statute. Id. at 428. See also id. at 426; AT\&T Co. v. United States, 299 U.S. 232, 236-37 (1936). Subsequent discussion will demonstrate that the current regulatory definitions do not exceed such limits of delegated authority.

${ }^{27}$ Pub. L. No. 73-66, 48 Stat. 162 (codified in scattered sections of 12 U.S.C. (1976)).

28 Two overriding purposes of the Act are useful background in examining section 371a. First, after the banking panic, financial authorities considered it essential to institute some means of deposit insurance in order to restore public confidence in the banking system and rebuild the bank lending base. H.R. REP. No. 150, 73d Cong., 1st Sess. 6 (1933). The Act therefore established the FDIC. Banking Act of 1933, Pub. L. No. 73-66, § 8, 48 Stat. 168 (current version at 12 U.S.C. $\$ \S 1811-1832$ (1976)). Second, Congress believed it necessary to disassociate commercial banking from investment banking as completely as possible. The use of commercial-bank credit for the purchase of securities was seen as one of the major causes of the stock market panic of 1929, S. REP. No. 77, 73d Cong., 1st Sess. 9 (1933). Many other bank practices in the twenties were also seen as encouraging excessive securities speculation, such as the underwriting of securities issues by commercial banks and the banks' maintenance of affiliates to engage in speculation with depositors' funds. Id. at 10 . Accordingly, the Act set up restrictions and prohibitions to keep the two types of banking functions separate, e.g., Banking Act of 1933, Pub. L. No. 73-66, $\S \S 3,9,21,48$ Stat. 162 (current versions at 12 U.S.C. $\$ \S 301,304,347,378(1976)$ ), and to restrict relationships between member banks and their affiliates, e.g., id. $\S \S 13,18,28$ (current versions at 12 U.S.C. $\S \S$ 52, 371c, 481 (1976)).

29 Staff of the Board of Governors of the Federal Reserve System, The Impact of the 
breadth of the bill, identification of motives behind specific provisions is difficult.

The most frequently advanced reason for section 371a's enactment is the "sound banking argument": without the interestpayment prohibition, banks would make imprudent loans and invest in overly risky securities that offered the prospect of high yields. The sparse legislative history, however, suggests that the sound banking argument was not a major motivating factor behind the prohibition. Rather, section 371 a was directed at three other problems: migration of funds from rural areas as a result of interbank depositing, dangerous concentration of large customer demand deposits, and the financial burden of FDIC insurance premiums. This section examines these three reasons for enacting section $371 \mathrm{a}$ as well as the sound banking argument, and concludes that the current regulatory definitions of bank deposits are consistent with the aims of all four.

1. The Sound Banking Argument. Many have argued that section 371a was designed to reduce the possibility that banks would engage in unwise investment practices. ${ }^{30}$ Allowing interest payments on demand deposits, the argument runs, would encourage active interest-rate competition between banks for demand-deposit funds. Such competition would force interest rates on deposits to such high levels that banks would be induced to make imprudent loans and investments in hopes of attaining higher rates of return. ${ }^{31}$

Payment of Interest on Demand Deposits 9 (1977) [hereinafter cited as The Impact of Payment].

30 E.g., Commission on Financial Structure and Regulation, Report ("The Hunt Commission Report") 27 (1971); Commission on Money and Credit, Money and Credit: Their Influence on Jobs, Prices and Growth 167 (1961); T. Simpson, Money, Banking and EcoNomic ANalysis 56-57 (1976); J. WhITE, BankING LaW 194 (1976); The Case of NOW Accounts, 84 U.S. INVESTOR/E. BANKER 339, 339-41 (1973).

3t Empirical studies have demonstrated that interest-rate competition probably does not lead to unsound investment policies. See Benston, Interest Payments on Demand Deposits and Bank Investment Behavior, 72 J. PoL. Econ. 431 (1964). Economic theory also fails to support this proposition. The sound banking argument rests on two erroneous premises. The first is that banks will make riskier investments when pressed for greater returns. Assuming relatively competitive markets, however, bankers will not make riskier loans in order to obtain greater rates of return; the higher interest earned on a risky loan will be offset by the higher potential for default. See, e.g., T. Simpson, supra note 30, at 118-19.

The second premise is that a restriction on the payment of interest on deposits will reduce the pressure on bank profits: if banks cannot compete for deposits through interest rates, they will not compete for deposits at all. Given a limited amount of funds available for deposits, however, banks will compete by offering other benefits, such as subsidized checking services. Thus, even if the temptation to make riskier investments were real, restrictions on interest payments would not encourage safer investments; banks would still spend the money saved by paying low (or zero) interest in competing for deposits. See generally THE IMPACT OF Payment, supra note 29, at 19-25. 
Defaults on the risky loans and failure of the unwise investments would sufficiently weaken banks so as to precipitate widespread closures and resulting panics. The argument concludes that prohibiting interest payments on demand deposits would reduce competitive pressure so that banks could hold less risky investments. ${ }^{32}$

Congressional adherence to the "sound banking" reasoning is, however, an inadequate explanation for section 371a, not because the enacting Congress thought the argument unpersuasive, but because it considered the argument only persuasive with respect to a different part of the statute-that concerning time deposits. In congressional debate, Senator Carter Glass, one of the authors of the 1933 Act, stated:

We confide to the Federal Reserve Board authority which it does not now possess in this connection to regulate interest on time deposits in order to put a stop to the competition between banks in payment of interest, which frequently induces banks to pay excessive interest on time deposits and has many tịmes over again brought banks into serious trouble. But that is a matter purely for regulation of the Federal Reserve Board. ${ }^{33}$

There is no indication that Senator Glass's concern over excessive interest-rate competition extended to demand deposits. Furthermore, Senator Glass felt that Congress could deal with the problem of interest-rate competition for time deposits by authorizing the Federal Reserve Board to regulate directly the interest paid on such deposits. Thus, the 1933 Banking Act contained a provision, ${ }^{34}$ codified to follow immediately after section $371 \mathrm{a}$, directing the Federal Reserve Board to limit by regulation the rates of interest that member banks may pay on time and savings deposits. ${ }^{35}$ The Federal Reserve Board currently prescribes and enforces these interest-rate restrictions ${ }^{36}$ along with section $371 \mathrm{a}$, through Regulation $\mathrm{Q}$.

In addition to the lack of any reference by Senator Glass to interest-rate competition for demand deposits, there is an affirma-

${ }^{32}$ See Linke, The Evolution of Interest Rate Regulation on Commercial Bank Deposits in the United States, 3 NaT'L Banking Rev. 449, 461 (1966).

3377 Cong. Rec. 3729 (1933) (remarks of Sen. Glass).

34 The Banking Act of 1933, Pub. L. No. 73-66, § 11(b), 48 Stat. 182 (current version at 12 U.S.C. $\S 371 b(1976))$.

35 Congress has also authorized the FDIC to prescribe, after consultation with the Federal Reserve Board and the Federal Home Loan Bank Board, allowable interest rates for nonmember insured banks. See 12 U.S.C. \& 1828(g) (1976).

${ }^{36} 12$ C.F.R. $\S 217.7$ (1979). The FDIC counterpart is codified at id. $\S \S 329.6-.7$. 
tive indication in later proceedings that Congress did not design section $371 \mathrm{a}$ to meet sound banking concerns. In hearings pursuant to the Banking Act of $1935,{ }^{37}$ two years after the enactment of section 371a, Senator Couzens suggested that section 371a had relieved banks of much competitive pressure, permitting them to save the money that without the prohibition would have been paid as interest on deposits. He thus appeared to suggest that section $371 \mathrm{a}$ had been enacted to address the concerns of the sound banking argument. Senator Glass, who played a major role in the passage of the 1933 Act, countered that the purpose of the prohibition was not to enable the banks to save money, but rather to discourage interbank depositing..$^{38}$

Apart from the absence of evidence in the legislative history supporting the sound banking argument, its logic fails to explain why Congress prohibited interest payments on demand deposits in section 371a, while merely allowing for regulation by the Federal Reserve Board of time and savings deposits. Congress found sound banking concerns to be pressing indeed with respect to competition in savings and time deposits (as opposed to demand deposits),,$^{39} \mathrm{but}$

${ }^{37}$ Pub. L. No. 74-305, 49 Stat. 684 (current version at scattered sections of 12 U.S.C. and at 11 U.S.C. $\S 101,15$ U.S.C. $\S \S 19,19 a(1976)$ ).

${ }^{33}$ For a discussion of the interbank-depositing argument, see text and notes at notes 45 . 73 infra. The 1935 colloquy took this course:

SENATOR Couzens. But you have been saved from a lot of competition that you used to encounter.

Mr. AlDRICH. Undoubtedly there has been a saving in the provision that we cannot pay interest on demand deposits.

SENATOR GLASS. The chief reason for putting that provision in the law was that the big banks were drawing all the surplus funds from the interior banks. That is why we put it in. We were not so much concerned about your making money. We were concerned about drawing all the money from the balance of the country.

Banking Act of 1935: Hearings on S. 1715 Before a Subcomm. of the Senate Banking and Currency Comm., 74th Cong., 1st Sess. 433-34 (1935) [hereinafter cited as 1935 Hearings].

39 There was reason for Congress to be more concerned with time than with demand deposits in this regard. The Federal Reserve Act had encouraged competition for time deposits by subjecting them to significantly lower reserve requirements than demand deposits. Rural banks were required to maintain $12 \%$ of their demand deposits and $5 \%$ of their time deposits as reserves; the fractions required of banks in "reserve cities" were $15 \%$ and $5 \%$ respectively, and of banks in "central reserve cities," $18 \%$ and $5 \%$ respectively. Federal Reserve Act, Pub. L. No. 63-43, §19(a)-(c), 38 Stat. 270 (1913) (current version at 12 U.S.C. $\S 461$ (b) (1976)). The apparent reason for this arrangement was that there was less of a chance for destructive runs on funds held in time deposits; as defined under the Act, they were subject to greater restrictions on withdrawals. But the lower reserve requirements on time deposits (which included savings deposits) also made the time deposits more attractive for the banks to hold, because lower levels of required reserves provided greater lending and 
found interest-rate regulation, rather than absolute prohibition, adequate to meet these concerns..$^{40}$ Moreover, Senator Glass indicated that sound banking objectives could be met "purely" through regulation by the Federal Reserve Board;"1 agency regulation such as that provided by Regulation $\mathrm{Q}$ (as opposed to statutory prohibition, such as section 371 a) was thus sufficient to guard against the dangers involved.

Even if the sound banking argument did contribute to the enactment of section 371a, its reasoning does not require that demand deposits be defined in terms of instruments of withdrawal, but remains fully compatible with the current regulatory definitions for the various types of deposits. ${ }^{42}$ In response to the sound banking argument, Congress would have prohibited the payment of interest on checking accounts only if banks were likely to engage in excessive competition for such accounts. But in 1933, banks did not generally pay interest on customer demand deposits, ${ }^{43}$ whether or not such accounts had checking services attached. Moreover, banks did not necessarily attach checking services to those few demand deposits that did bear interest-interbank deposits and the deposits of large businesses, governmental units, and wealthy individuals. ${ }^{44}$

2. Interbank Deposits. Congress most likely enacted section $371 \mathrm{a}$ to reduce interbank depositing, the practice by which banks in outlying areas redeposited their reserves with banks in financial centers. In attempting to curb interbank-depositing activities, Congress first enacted the Federal Reserve Act $^{45}$ in 1913, requiring all member banks to maintain a specified proportion of their reserves

earning capability. Legislators discerned a large incentive for bankers to compete with each other for time and savings deposit funds through the offering of successively higher rates of interest. See Linke, supra note 32 , at 460.

10 One group of experts seems to have recognized that regulation of time-deposit interest payments and prohibition of demand-deposit interest payments were designed to fulfill separate functions, and that the sound banking argument related only to the former. See THE Committee on Financial Institutions, Report to the President of the United States 19 (1963) [hereinafter cited as HeLLen REPORT].

"See text at note 33 supra.

12 Modern banking regulations directly regulate both types of bank activities involved in the sound banking argument: imprudent lending to speculators on collateral of securities purchased with the loan, and direct investment by banks in risky securities. See Federal Reserve Board Regulation U, 12 C.F.R. $\$ 221$ (1979) (imposing "margin requirements" on investment-security loans using securities as collateral); Investment Securities Regulation of the Comptroller of the Currency, id. $\S 1$ (limiting the types of investments banks may purchase, sell, and underwrite).

${ }^{43}$ See Linke, supra note 32, at 457 n.31.

"See id.

${ }^{45}$ Pub. L. No. 63-43, 38 Stat. 251 (1913) (current version at scattered sections of 12 U.S.C. and at 31 U.S.C. $\$ 409$ (1976)). 
in deposits at the federal reserve banks. ${ }^{46}$ Yet interbank depositing continued long after 1913, and thus, according to the legislative history of section $371 \mathrm{a}$, played a significant role in the enactment of the 1933 prohibition.

a. Early Concern over Interbank Depositing. The National Banking Act of 1864 required rural banks to maintain $15 \%$ of their deposits in reserve while requiring banks in selected cities to maintain $25 \%$ of their deposits in reserve. ${ }^{47}$ These reserve funds, however, were to a large extent fictitious, since the Act permitted country banks to deposit three-fifths of their reserves with the designated city banks ${ }^{48}$ and permitted the city banks to deposit one-half of their reserves with national banks in New York City. ${ }^{49}$ Reserves were thus not immediately available for meeting actual drains if the country and city banks redeposited their funds to the extent permitted. ${ }^{50}$ The New York banks paid interest on the redeposited funds to the rural and city banks, a practice which appears to have encouraged by "pyramiding" of reserves. .1 $^{2}$

These redeposited reserves were a type of interest-bearing demand deposit that commentators have called "bankers' balances." Typically, country banks placed all of their allowable reserves in bankers' balances with city banks, and city banks placed all of their allowable reserves in bankers' balances with New York banks. The arrangement had the appearance of safety because the bankers' balances, being demand deposits, could always be repaid on short notice.

The New York banks could afford to pay interest on the redeposited funds because they in turn would often lend them to securi-

16 Federal Reserve Act, Pub. L. No. 63-43, $\S 19$ (a)-(c), 38 Stat. 270 (1913) (current version at 12 U.S.C. $\S 461$ (b) (1976)). See also H.R. ReP. No. 69, 63d Cong., 1st Sess. 20 (1913). The House Committee on Banking and Currency stated that the only way to prevent the destructive effects of interbank depositing was to "provide for the holding of reserves by duly qualified institutions which shall act primarily in the public interest"-the federal reserve banks. Id. See text at notes $48-49$ infra.

4 Act of June 3,1864 , ch. 106, $\S 31,13$ Stat. 108 (current version at 12 U.S.C. $\S 461$ (b) (1976)).

" Id., 13 Stat. 109 (superseded by Federal Reserve Act, Pub. L. No. 63-43, § 19(a)-(c), 38 Stat. 270 (1913) (current version at 12 U.S.C. $\$ 461$ (b) (1976))).

10 Id., § 32, 13 Stat. 109 (superseded by Federal Reserve Act, Pub. L. No. 63-43, § 19(a)-

(c), 38 Stat. 270 (1913) (current version at 12 U.S.C. \& 461(b) (1976))).

${ }^{50}$ L. Chandler, The Economics of Money and Banking 95 (5th ed. 1969).

${ }^{51}$ See H.R. Rep. No. 69, 63d Cong., 1st Sess. 20 (1913); Linke, supra note 32, at 452. But see note 57 infra.

52 Gendreau, Bankers' Balances, Demand Deposit Interest, and Agricultural Credit before the Banking Act of 1933, $11 \mathrm{~J}$. MoNEY, CREDIT, \& BankING 506, 506 (1979); Linke, supra note 32 , at 450 . 
ties brokers through what were known as "call loans."53 In exchange, the brokers could pay the New York banks sufficiently high rates of interest to compensate them profitably for the payments due the outlying banks. At any time, a New York bank could "call" its loan to a security broker; when called, the broker frequently would liquidate some of his investments to repay the principal.

Normally, this system worked reasonably well; when an order came through from a country bank for a withdrawal, the city bank would notify the New York bank where its reserves were redeposited and the New York bank would call the necessary amount of its loans to stock brokers. The brokers could then sell securities to repay the loans and the funds would work their way back to the country bank.

The demand for funds from rural banks was, however, chiefly seasonal; it was not uncommon for many rural banks to withdraw their bankers' balances nearly simultaneously. When they did so, the New York banks were forced to call the loans they had made to brokers. If the securities market was weak, brokers were often unable to repay their loans. Securities prices would be too low to satisfy the amount required, and borrowing from other banks would be difficult.

When New York banks could not collect their call loans, they could either dishonor the withdrawal requests or pay them from their own reserves. On more than one occasion, the New York banks chose to dishonor the requests. ${ }^{54}$ In such instances, the country and city banks that had relied on the availability of their redeposited reserves had to suspend payments to their depositors, and, when word spread that certain banks were suspending payments, banking panics often ensued. This chain of events was largely responsible for the banking panics of $1857,1873,1884,1893$, and $1907 .{ }^{55}$ Thus, even in the years before the Federal Reserve Act, banking organizations suggested ${ }^{56}$ that prohibiting interest payments on bankers' balances

${ }^{53}$ One authority has asserted that the existence of the bankers' balances procedures was responsible for the development of the call-loan market. Linke, supra note 32, at $452 \mathrm{n} .12$ (citing 1 M. Myers, The New York Money Market 126-48, 265-67 (1931)).

.54 R. Thomas, Our Modern Banking ANd Monetary System 219 (4th ed. 1964).

${ }^{55}$ See Linke, supra note 32 , at 452.

ss In 1873, for example, the New York Clearing House, a confederation of New York bankers, alarmed by the panic of that year, vigorously recommended the prohibition of interest payments on bankers' balances. After the panic of 1884, the banks themselves mutually agreed to limit interest payments on bankers' balances, but the banks then undermined the plan by manipulating service charges. See id. at $453-56$. As early as 1851 , the Bank Commissioners of Massachusetts expressed concern that interest payments on bankers' balances were impairing rural credit availability. See Gendreau, supra note 52, at 507. 
would sufficiently discourage interbank depositing so as to reduce the threat of panics. ${ }^{57}$

The Federal Reserve Act increased financial stability by requiring member banks to maintain their required reserves in a federal reserve bank or as cash in vault $t^{58}$ and by providing lending facilities in the event of a liquidity crunch. ${ }^{59}$ It then became impossible for outlying banks to pyramid their required reserves. The Act thereby averted the danger that banking panics would result from unavailability of basic reserves. Outlying banks, however, continued to deposit excess, or secondary, reserves with banks in financial centers. ${ }^{60}$

b. Interbank Depositing After the Federal Reserve Act. The enactment of section 371a in 1933 was in part attributable to the continued practice of interbank depositing. Indeed, the legislative history of the 1933 interest-payment prohibition demonstrates that Congress believed a reduction in interbank depositing would benefit rural areas: curbing the migration of bank funds from outlying areas to urban centers might induce country banks to lend their excess funds to local residents. Recent commentators have also suggested that the belief that interbank depositing was partly responsible for the stock market crash of 1929 was instrumental in the enactment of section $371 \mathrm{a}$.

i. Local Lending. In the debates on the 1933 Banking Act, Senator Glass made explicit the basis for his support of the legislation. "The payment of interest on demand deposits has resulted for years and years," he declared, "in stripping the country banks

57 It is unlikely, however, that interest payments were the primary motivation in the redepositing mechanism. See Gendreau, supra note 52, at 507, 513. For most of the period prior to enactment of section $371 \mathrm{a}$, the market lending rate was considerably higher than that paid on bankers' balances. Rural bankers probably redeposited funds in order to maintain balances with correspondents, to facilitate check clearing and interbank transactions, to maintain short-term investments for portfolio diversification, and to preserve liquidity against seasonal swings in deposits and loans. See The IMPACT OF PAYMENT, supra note 29, at 11; Gendreau, supra note 52, at 508. Nevertheless, the proportion of federal reserve bank liabilities held as bankers' balances declined after the enactment of section 371a. At the end of $1933,76 \%$ of deposits at the federal reserve banks for member banks were bankers' balances. By 1937 , they had fallen to $49 \%$, and by 1948 they had fallen to $28 \%$. See M. FriedmaN \& A. Schwartz, A Monetary History of the United States 1867-1960, at 444 (1963).

ss Federal Reserve Act, Pub. L. No. 63-43, § 19(a)-(c), 38 Stat. 270 (1913) (current version at 12 U.S.C. $\$ 461$ (b) (1976)).

59 Id. $\S 13,38$ Stat. 263, as amended by Act of Sept. 7, 1916, Pub. L. No. 64-270, 39 Stat. 752 (current version at 12 U.S.C. $\$ 347$ (1976)).

${ }^{\text {s0 }}$ Linke, supra note 32, at 458. See generally R. Thomas, supra note 54, at 193.

61 There are only two direct references to section $371 \mathrm{a}$ in the 1933 record. The other, less forceful than that presented here, is discussed in text and notes at notes 79-83 infra. 
of all their spare funds, which have been sent to the money centers for stock speculative purposes."62 The Federal Reserve Act had failed to stem the outflow of rural funds, and the 1933 Act, by directing its force at the underlying incentive-interest payments-might curb the migration..$^{63}$ Two years later, Senator Glass, in Senate hearings on the Banking Act of 1935, again pinned the impetus behind the enactment of section 371a on local-lending concerns: "the withdrawal of all the interior funds of the country banks and the transferring of them to the money centers for speculative purposes . . . was a major reason why we prohibited the payment of interest on demand deposits."

Although modern economists have doubted that interest payments on interbank deposits played a major role in the practice of interbank depositing, ${ }^{65}$ the 1933 Congress seems to have acted on that very belief in enacting section $371 a .^{66}$

ii. Excessive Speculation. Section 371a may have been enacted to address another concern: excessive speculation. In 1933, conventional wisdom maintained that too much money had been available for speculation in the securities market during the 1920s. Excessive speculative use of bank credit, it was argued, led to higher prices and genuine fear of future values, ${ }^{67}$ and was in part responsible for the 1929 collapse of the stock market. ${ }^{68}$ According to this

6277 Cong. REc. 3729 (1933) (remarks of Sen. Glass).

63 Senator Glass continued:

When we adopted the Federal Reserve Act and rescued the reserve funds or trust funds of the national banking system from the stock gamblers we had hoped that that would be a salutary lesson to all member banks of the system. We had hoped that they were no longer in involuntary servitude to their correspondent banks and that they would deal with the regional reserve banks rather than with the banks in the money centers. But Id. we have been disappointed in that respect.

os 1935 Hearings, supra note 38 , at 492 . Senator Glass explained:

[C]ountry banks had what they call standard rates of discount. It is almost impossible ever to get them to depart from that standard rate of discount. They would rather bundle up their surplus funds and send them to the money centers at a nominal rate of 2 percent than to give the merchants of the town or the industries of the town or the locality the benefit of an abundance of money and an abundance of credit.

Id. See also text and notes at note 38 supra.

${ }^{65}$ See note 57 supra.

${ }^{65}$ Subsequent developments have made the local-lending argument obsolete. Special federal programs provide loans for farmers. See, e.g., Farm Credit Act of 1953, Pub. L. No. $83-202,67$ Stat. 390 (current version at scattered sections of 12 U.S.C. and at 7 U.S.C. $\$ 452$ note (1976)). In addition, urban banks are now accessible to farmers. See The Impact of PAYMENT, supra note 29, at 12.

67 See R. Thomas, supra note 54 , at 219.

os See R. Kent, Money and Banking 343-44 (4th ed. 1961). 
view, the many call loans made available to securities brokers by banks only aggravated the economic injury caused by excessive speculation, and if the loans were recalled at a time when prices were excessive, panic conditions might result more easily.

Recent authorities have suggested that section 371a was in part designed to reduce excessive speculation and curtail activity in the call-loan market by removing the interest-payment incentive for depositing the excess funds of interior banks with New York banks. ${ }^{69}$ Although the statements of Senator Glass quoted above ${ }^{70}$ evince a distaste for stock speculation generally, there is no indication in the record that Congress enacted section 371a to preserve stock market stability. This rationale is all the more unlikely since other parts of the 1933 Act dealt more directly with the relationship between commercial banking and securities speculation. For example, the Act placed restrictions on federal reserve banks designed to limit them to extending credit for commercial rather than speculative purposes. ${ }^{71}$ The Act prescribed punitive measures for member banks that increased their loans to speculators while holding outstanding notes from federal reserve banks, ${ }^{72}$ and also prohibited institutions engaged in the issuing, underwriting, selling, or distributing of securities from receiving deposits. ${ }^{73}$

The continuation of interbank depositing into the 1930s undoubtedly troubled the legislators who enacted section $371 \mathrm{a}$. That section 371a was directed at the problem of interbank depositing, however, does not require an "instruments definition" of demand deposits-one that would comprehend all personal checking accounts. The demand deposits that legislators in 1933 believed to have caused the migration of funds from rural areas were institutional interbank deposits, bearing little similarity to personal demand deposits dispensed through checks.

3. Individual Demand Deposits. Although Congress probably intended section $371 \mathrm{a}$ to increase lending in rural areas by discouraging redepositing of secondary reserves, this same goal could have been achieved by prohibiting interest payments only on interbank deposits, rather than on all demand deposits. This puzzling overinclusiveness results in the irony that section 371a's most widespread effect, that on individual checking-account holders, is not dictated

"See Heller Report, supra note 40, at 19. See also R. KENT supra note 68, at 219.

${ }^{70}$ See text and notes at notes 62-64 supra.

"Pub. L. No. 73-66, § 3, 48 Stat. 163 (current version at 12 U.S.C. $\S 301$ (1976)).

${ }^{72}$ Id. $\S 9,48$ Stat. 180 (current version at 12 U.S.C. $\S 347$ (1976)).

${ }^{3} I d . \S 21(\mathrm{a})(1), 48$ Stat. 189 (current version at 12 U.S.C. $\S 378(1976)$ ). 
by the arguments most instrumental in its passage. The overinclusiveness becomes all the more puzzling in light of the fact that in 1933 banks did not generally pay interest on the demand deposits of individual customers. ${ }^{74}$

Remarks made by Senator McAdoo during hearings on the Banking Act of $1935^{75}$ provide one possible explanation for the inclusion of individual demand deposits in the section 371a prohibition. The Senator indicated that excessive competition for depositors' funds had encouraged banks to offer wealthy customers high interest rates in return for placing large sums of money in demand deposits, even though banks did not generally pay interest on the demand deposits of individuals. "[G]reat abuses had risen out of that practice," alleged the Senator:

The bidding by banks against each other for the deposits of customers who had large deposits and who were relatively highly favored while the small depositors got practically nothing. [sic] It led to unwholesome competition between the banks and an unwholesome condition, so far as demand deposits were concerned, because the big depositors usually had some knowledge of what might happen and they pulled their deposits out when they got scared, which weakened the condition of the bank more than the withdrawals of a large number of small deposits. ${ }^{76}$

Congressmen may have believed that a prohibition of demanddeposit interest payments would inhibit the use of this device to attract individual demand-deposit customers. "[W] here interest was not paid on demand deposits, and deposits might be more widely distributed," Senator McAdoo noted, "less injury might follow from a large number of small withdrawals." 7

These remarks, although not part of the legislative history of the 1933 Act, still provide a plausible explanation for the applica-

${ }^{7}$ See Linke, supra note 32 , at 457 n.31.

${ }^{75}$ Pub. L. No. 74-305, 49 Stat. 684 (current version at scattered sections of 12 U.S.C. and at 11 U.S.C. $\$ 101,15$ U.S.C. $\$ \S 19,19 a(1976)$ ).

${ }^{76} 1935$ Hearings, supra note 38, at 491 (remarks of Sen. McAdoo). The Senator provided a specific example:

In the city of Los Angeles, a city of 1,250,000 people, with quite a large number of banks, the abuse got to be very great, so bankers have informed me. One bank would offer a large depositor a very much higher rate of interest than was justified, and at the first sign of trouble this large depositor got uneasy and withdrew his whole deposit at once, which was a very bad thing for the bank, or it might have been . . . .

Id.

nId. 
tion of the ban to individual demand deposits as well as interbank demand deposits. Acceptance of this explanation, however, does not require that demand deposits be defined in terms of checking services. In fact, it supports the current Federal Reserve Board definition: the determinative feature of a demand deposit is the ability of the depositor to demand payment with little or no notice. ${ }^{78} \mathrm{It}$ was this feature of demand deposits that Congress believed critical in maintaining bank stability, not the form in which the withdrawal was made.

4. Insurance Premiums. The legislative history of the 1933 Banking Act indicates that Congress was addressing one more concern in enacting section 371a. As part of the Act, Congress adopted a plan to insure deposits through the creation of the FDIC, ${ }^{79}$ To finance this plan, the Act imposed a levy of $1 / 2 \%$ on all bank deposits. ${ }^{80}$ Such a levy might have severely strained bank profits at a time when many banks were facing financial difficulty. Senator Glass argued in congressional debate that the money saved by prohibiting the payment of interest on demand deposits would more than offset the new insurance assessments. ${ }^{81}$

The prohibition of the payment of interest on demand deposits was at least partly intended to alleviate the strain on bank profits caused by insurance premiums. The fulfillment of this objective, however, did not require that "deposit[s] which [are] payable upon demand"s2 include checking accounts. Banning interest payments on demand deposits would save banks the expense of paying interest whether or not checking services were attached to the deposits. Indeed, as indicated earlier, ${ }^{83}$ the few demand deposits for which banks did pay interest were large deposits of wealthy custom-

${ }^{78}$ See text and note at note 25 supra.

7 See note 28 supra.

sub. L. No. 73-66, § 8, 48 Stat. 168 (1933) (current version at 12 U.S.C. $\S 1817(b)(1)$ (1976)).

st The banks of the country almost universally are protesting against the assessment of one half of 1 percent upon their time and demand deposits . . . The aggregate of the sum that will be exacted from the member banks under the one half of 1 percent assessment in order to insure the deposits in all the member banks is $\$ 175,000,000$. If the banks are relieved of the competitive necessity of bidding for demand deposits on interest, they will not only have money to meet this assessment of one half of 1 percent to insure deposits, but they will have almost an equal amount left over. I have no doubt in the world that a vast majority of the commercial banks of the country will be glad to be prohibited by law from engaging in this competition of interest on demand deposits. 77 Cong. REc. 4168 (1933) (remarks of Sen. Glass). Senator McAdoo also supplied this rationale at the hearings for the 1935 Act. See 1935 Hearings, supra note 38, at 492.

s2 See text at note 15 supra.

s See text and notes at notes 74-78 supra. 
ers, which are most unlikely to have involved checking services.

Thus, the original purposes of section 371 a do not indicate that Congress meant to proscribe the payment of interest on checking accounts. The major concerns that led to the enactment of section $371 a$-interbank depositing, the volatility of large individual deposits, and the burden of insurance premiums-are wholly unrelated to the manner in which funds are withdrawn from an account.

\section{The 1913 Definitions}

The contemporary economic concerns that led the 1933 Congress to enact section $371 \mathrm{a}$, as described in the previous section, suggest that the current regulatory scheme-defining demand deposits without regard to the instruments used in making withdrawals-is completely consistent with the purposes of the 1933 prohibition. The consistency of the present regulatory definitions with section $371 \mathrm{a}$ is further supported by the close similarity of the current regulations to statutory definitions in force at the time Congress enacted section 371a.

The Federal Reserve Act ${ }^{84}$ established reserve requirements for all deposits at member banks, and the level of reserves required of each bank depended in part on the relative levels of time and demand deposits held by that bank. ${ }^{85}$ Section 19 of the Act defined demand deposits as "deposits payable within 30 days," and time deposits as "deposits payable after thirty days, and all savings accounts and certificates of deposit which are subject to not less than thirty days' notice before payment." ${ }^{86}$ When Congress enacted the 1933 Banking Act, it inserted section 371a into section 19 of the Federal Reserve Act. ${ }^{87}$ Section 371a's prohibition thus addressed demand deposits as defined by the Federal Reserve Act; the definitions of the 1913 Act were effective "within the meaning" of the entire Act. ${ }^{88}$ The insertion of section $371 a$ into the Federal Reserve Act dispels any notion that Congress contemplated a popular, non-

\& Pub. L. No. 63-43, 38 Stat. 251 (1913) (current version at scattered sections of 12 U.S.C. and at 31 U.S.C. $\S 409$ (1976)).

${ }^{85}$ Id. $\S 19(\mathrm{a})$-(c), 38 Stat. 270 (current version at 12 U.S.C. $\S 461(\mathrm{~b})$ (1976)). The level of reserves also varied depending on whether the bank was a country bank, id. $\S 19(\mathrm{a})$, "reserve city bank," id. $\$ 19(\mathrm{~b})$, or "central reserve city bank," id. $\S 19$ (c).

s6 Id. § 19, 38 Stat. 270 (superseded by 12 U.S.C. $\$ 461$ (a) (1976)).

87 The definitions had occupied the first paragraph of section 19; the 1933 Act amended section 19 by "adding at the end thereof" the section 371a language. Banking Act of 1933, Pub. L. No. 73-66, § 11(b), 48 Stat. 181.

Federal Reserve Act, Pub. L. No. 63-43, $\S 19,38$ Stat. 270 (1913) (superseded by 12 U.S.C. § 461(a) (1976)). 
technical meaning of demand deposits, such as one equating them with checking accounts, in enacting the 1933 prohibition.

\section{Regulatory Interpretations}

The application of the 1913 definition of demand deposits to section 371a establishes that the 1933 Congress did not consider a statutory instruments definition essential for the purposes of section 371a. Nevertheless, from 1933 to 1978 the financial agencies promulgated regulations contemplating an instruments definition of demand deposits. ${ }^{89}$ It has been suggested that such a consistent pattern of regulatory interpretation implies that the current regulations, diametrically opposed to the established pattern, are invalid. ${ }^{90}$ This argument gains force in view of the Federal Reserve Board's promulgation, from 1913 to 1933, of an instruments definition of demand deposits for the setting of reserve requirements. The Federal Reserve Board continued to use its instruments definition after the promulgation of Regulation $Q$ in 1933, but in 1935 this definition acquired added authority when Congress replaced the Federal Reserve Act statutory definition with a grant of definitional authority to the Federal Reserve Board and the FDIC.

1. The Pre-1935 Regulatory Definition. The Federal Reserve Board first promulgated an instruments definition of savings accounts in 1913 as part of Regulation D, issued pursuant to its authority to enforce reserve requirements. ${ }^{91}$ Regulation $\mathrm{D}$ defined savings accounts as accounts from which withdrawals could be made only by passbook. ${ }^{22}$ In 1923 , in a ruling applying this definition, the Federal Reserve Board held that savings accounts with checking

8 Moreover, since 1962, the Federal Reserve Board and the FDIC have explicitly prohibited AFTs by regulation. See 26 Fed. Reg. 12,031, 12,032 (1961). This was the regulatory ban the agencies rescinded in 1978. See text and notes at notes 1-5 supra.

so.g., Note, Challenging the Scope of Agency Authority in Issuing Banking Regulations: The Validity of Automatic Funds Transfers for Commercial Banks, 59 B.U. L. Rev. 372, 386 (1979); Consolidated Points and Authorities, supra note 3, at 47.

"The Federal Reserve Act empowered the Board to "make all rules and regulations necessary to enable said board effectively to perform" its duties, functions, and services. 12 U.S.C. § 248(i) (1976).

12 The term "savings accounts" shall be held to include those accounts of the bank in respect to which, by its printed regulations, accepted by the depositor at the time the account is opened-

(a) The pass book, certificate, or other similar form of receipt must be presented to the bank whenever a deposit or withdrawal is made, and

(b) The depositor may at any time be required by the bank to give notice of an intended withdrawal not less than 30 days before a withdrawal is made.

9 Fed. Res. Bull. 897 (1923). 
services attached were subject to the reserve requirements of demand deposits rather than the lower requirements of time deposits..$^{93}$

The legal basis for either the instruments definition of savings accounts or the 1923 ruling is not clear. Although federal banking authorities are authorized to scrutinize the activities of all member banks, presumably including their maintenance of required reserves, ${ }^{94}$ Congress has always prescribed reserve requirements by statute, either precisely or within a specified range. ${ }^{95}$ At the time of section 371a's enactment, the Federal Reserve Act specified that demand-deposit reserve requirements be met for accounts payable in thirty days and that only the lower time-deposit reserve requirements be met for accounts not payable within thirty days. ${ }^{96}$ The Federal Reserve Board's insistence that demand-deposit reserve requirements be met for accounts with checking services was thus inconsistent with the statute and, in effect, a modification of the reserve requirements set by Congress.

The definitions remained inconsistent despite the fact that the Federal Reserve Act did not explicitly define savings accounts, but merely stated that time deposits included savings deposits subject to thirty-days notice of withdrawal. Under the Act, a deposit could be a demand deposit if "payable within thirty days" and at the same time a savings deposit that did not qualify as a time deposit because it was "not subject to thirty days' notice before payment." For purposes of the Act, it was necessary only to distinguish between time and demand deposits to determine reserve requirements. An

${ }^{23}$ Id. at 677 . The particular plans involved, devised by certain enterprising state member banks in California, were called "special savings deposits," and were rather like modern NOW accounts, see text and notes at notes 115-126 infra, in that the bank reserved a thirtyday notice option on the savings deposit but allowed withdrawal by check.

" The Comptroller of the Currency is required to appoint bank examiners to investigate all national banks at regular intervals, 12 U.S.C. $\$ 481$ (1976), and the Federal Reserve Board may authorize examination of state member banks by state authorities, $i d$. Additionally, the Federal Reserve Board has authority to prescribe such regulations as it deems necessary to effectuate the purposes of the statutes dealing with the reserve requirements, id. § 461(a).

${ }^{95}$ Starting with the Federal Reserve Act, Pub. L. No. 63-43, \& 19(a)-(c), 38 Stat. 270 (1913) (current version at 12 U.S.C. $\$ 461$ (b) (1976)), and continuing under the revisions of the Act of June 21, 1917, Pub. L. No. 65-25, $\S 10,40$ Stat. 239, the setting of reserve requirements had been completely statutory. With the Act of Sept. 21, 1966, Pub. L. No. 89-597, $\S$ $2(a), 80$ Stat. 823 , Congress introduced an element of discretion into the setting of required reserves, but still directed the Federal Reserve Board to remain within a prescribed margin of percentages.

"s Federal Reserve Act, Pub. L. No. 63-43, § 19(a)-(c), 38 Stat. 270 (1913), as amended by Act of June 21, 1917, Pub. L. No. $65-25, \S 10,40$ Stat. 239 (current version at 12 U.S.C. $\S$ 461(b) (1976)). 
account that met the definitions of both a savings deposit and a demand deposit would simply be a savings deposit subject to the demand-deposit reserve requirements. Although Regulation D seemed to define only savings accounts, which were not explicitly defined by statute, its subsequent application resulted in a substantive modification of the statutory definition of demand deposits.

Not only is the legal basis for the Federal Reserve Board's 1913 instruments definition of savings deposits doubtful, it is unlikely that Congress relied on that definition rather than its own statutory definition when it enacted section 371a. The definition in Regulation $\mathrm{D}$ was designed to regulate the reserve practices of member banks. There is no reason to assume that when Congress enacted section $371 \mathrm{a}$ it intended the statutory prohibition to be interpreted in light of agency regulations aimed at achieving different ends. It is much more reasonable to interpret the prohibition in light of the statutory definition that governed section 371a.

In 1933, pursuant to its authority to enforce section 371a and regulate interest rates on time deposits, the Federal Reserve Board promulgated Regulation $\mathrm{Q}$ which, again, included in the definition of savings accounts a requirement that withdrawals be made only upon presentation of a passbook..$^{97}$ In 1934, the Federal Reserve Board made clear that it had promulgated this definition to enforce section 371a and implied that demand deposits and savings deposits were mutually exclusive. ${ }^{98}$ The Board's decision was again inconsistent with the statute. Under the statutory definitions, savings accounts and demand deposits were not mutually exclusive and demand deposits were defined only as accounts payable within thirty days.

Although some weight should be given an agency's prior interpretation of the statutes it is assigned to enforce, ${ }^{99}$ the Federal Reserve Board's early interpretations of the Federal Reserve Act do not indicate that AFTs are illegal. The pre-1935 interpretations are in-

1719 Fed. Res. Bull. 571, 573 (1933).

\&s 20 id. 389 (1934).

" Courts and commentators often cite a statement in Skidmore v. Swift \& Co., 323 U.S. 134,140 (1944), that "[t]he weight of [an agency's] judgment in a particular case will depend upon . . . its consistency with earlier and later pronouncements," as authority for this proposition. See General Elec. Co. v. Gilbert, 429 U.S. 125, 142 (1976); Consolidated Points and Authorities, supra note 3 , at 47 . An often-cited corollary allows an agency to change its mind if it indicates that "the standard is being changed and not ignored, and assur[es] that it is faithful and not indifferent to the rule of law." Columbia Broadcasting Sys., Inc. v. FCC, 454 F.2d 1018, 1026 (D.C. Cir. 1971), quoted in Chisholm v. FCC, 538 F.2d 349, 364 (D.C. Cir.), cert. denied, 429 U.S. 890 (1976), and Consolidated Points and Authorities, supra note 3 , at 52 . 
consistent with, and a modication of, the statutes enacted by Congress.

2. The Post-1935 Definitions. Congress eliminated the inconsistencies between the statute and the regulations in 1935, when it rescinded the statutory definitions and authorized the Federal Reserve Board to promulgate regulations defining types of deposits. ${ }^{100}$ Under the Regulation Q definitions adopted in 1935, the Federal Reserve Board explicitly declared savings deposits and demand deposits to be mutually exclusive: demand deposits were defined as deposits that were not time deposits or savings accounts, and savings accounts continued to be defined according to the permissible instruments or methods of withdrawal. ${ }^{101}$

In 1962, the Federal Reserve Board removed the instrumentsof-withdrawal element from the definition of savings deposits. ${ }^{102}$ Since demand deposits continued to be defined as deposits that were not savings or time deposits, ${ }^{103}$ demand deposits were once again defined independently of the instruments used in making withdrawals. This definitional change, however, had little substantive effect. Another part of Regulation Q, described as enforcing section 371a, continued to prohibit most withdrawals from savings accounts other than upon presentation of a passbook or through personal payment, ${ }^{104}$ and explicitly prohibited AFTs. ${ }^{105}$ Over the following years, the Federal Reserve Board and the FDIC liberalized withdrawal methods for savings accounts, authorizing both automatic transfers to pay periodic bills to specified creditors ${ }^{108}$ and

100 Banking Act of 1935, Pub. L. No. 74-305, § 324(a), 49 Stat. 714 (amending Federal Reserve Act, Pub. L. No. 63-43, $\$ 19,38$ Stat. 270 (1913)) (current version at 12 U.S.C. $\$$ 461(a) (1976)).

10121 Fed. Res. Bull. 863 (1935).

10226 Fed. Reg. 12,031 (1961) (current version at 12 C.F.R. $\$ 217.1$ (e) (1979)). The FDIC altered its regulations in the same way. 26 Fed. Reg. 12,032 (1961) (current version at 12 C.F.R. $\$ 329.1($ e) (1979)). This was also the occasion of the imposition of the AFT ban. See note 89 supra.

${ }^{103} 12$ C.F.R. $\S \S 217.1(a), 329.1(a)$ (1959 \& Supp. 1962).

10 26 Fed. Reg. 12,031, 12,032 (1961) (current version at 12 C.F.R. $\S \S 217.5(c)(1)$, $329.5(c)(1)$ (1979)) (previously codified at 12 C.F.R. $\S \S 217.1(e)(2), 329.1(e)(2)$ (1959 \& Supp. 1962)).

${ }_{105} 26$ Fed. Reg. 12,031, 12,032 (1961) (previously codified at 12 C.F.R. $\S \S 217.1(\mathrm{e})(3)$, 329.1(e)(3) (1959 \& Supp. 1962)) (rescinded by 43 Fed. Reg. 20,001, 20,222 (1978)).

${ }_{108} 40$ Fed. Reg. 16,685, 33,198 (1975) (codified at 12 C.F.R. $\$ \S 217.5$ (c)(1)(vii), 329.5(c)(1)(vi) (1979)), reprinted in [1973-1978 Transfer Binder] FED. BANKING L. REP. (CCH) If 96,519. The regulatory history of the authorization for bill-payer services is an example of the basic change in attitude that the agencies have exhibited concerning the purposes of the withdrawal restrictions. The first version of the authorization permitted thirdparty payments only of interest, principal, or other charges due on a real estate loan, apparently in deference to a policy of maintaining the health of the construction industry. 26 Fed. 
telephone transfers. ${ }^{107}$ Finally, in 1978 , the agencies authorized AFTs. ${ }^{108}$

The post-1935 interpretations, unlike the pre-1935 interpretations, appear to be within the scope of the discretion Congress conferred on the Federal Reserve Board when it authorized the Board to define demand, time, and savings accounts by regulation. Hence, the current regulations-permitting AFTs-are invalid only if they constitute an abuse of the Federal Reserve Board's discretion. ${ }^{109}$ Yet the current definitions are consistent with both the intent of Congress in enacting section $371 \mathrm{a}$ and the statutory definitions under which section 371 a was enacted.

\section{Withdrawals by Negotiable Instrument-Section 1832}

The second challenge to the legality of AFTs is based on section 1832 of Title 12 of the United States Code. ${ }^{10}$ That statute prohibits withdrawals by negotiable instrument from interest-bearing accounts, and was enacted in 1973 as a congressional response to the emergence of NOW accounts in Massachusetts and New Hampshire the previous year. ${ }^{111}$ The original statute permitted NOW accounts to continue in those two states, but prohibited them in the other

Reg. 12,031, 12,032 (1961). More recently the agencies have expanded the category of acceptable payees. See text and notes at notes 147-148 infra.

${ }_{107} 40$ Fed. Reg. 16,831 (1975) (codified at 12 C.F.R. $\$ 217.152$ (1979)), reprinted in [19731978 Transfer Binder] Fed. BankINg L. REp. (CCH) \96,522. See text and note at note 146 infra.

10 43 Fed. Reg. 20,001, 20,222 (1978) (amending 12 C.F.R. $\S \S 217.5(c)(2), 329.5(c)(2)$ (1978)), reprinted in [1978-1979 Transfer Binder] FED. Banking L. ReP. (CCH) If 97,432, 97,437 .

10 See note 26 supra. Because the withdrawal restrictions have been nondefinitional since 1962, it could be argued that since 1962 the restrictions have not been within the Board's discretionary authority to define bank accounts and must have been considered mandated by section 371a. Since the Board did, however, have the authority to define bank accounts, there would have been little incentive for a bank to challenge the regulations-at most, the Board would only have had to move the withdrawal restrictions back into the definitions.

Although the Federal Reserve Board's regulations were never overturned in court during the period from 1913 to 1978 , it is not necessarily true that the Board's approach was generally accepted as the proper and necessary interpretation of the relevant statutes. During most of the time the regulations have been in effect, there has been little incentive to offer checking services with savings accounts and, therefore, little incentive to challenge the Board's regulations. Until the 1950s, market rates of interest were low and deposit interest rates were well below regulatory ceilings. G. KaufMan, Money, tHe Financial System, aND THE Economy 98 (1973). Thus, until the 1950s, the value of checking services to depositors was never significantly lower than interest rates.

11012 U.S.C. $\$ 1832$ (1976). See text at note 127 infra.

"I' For a description of the development of NOW accounts in Massachusetts mutual savings banks, see Riordan, Negotiable Orders of Withdrawal, 30 Bus. LAw. 151 (1974). 
forty-eight. ${ }^{112}$ Subsequent amendments ${ }^{113}$ authorized depository institutions to offer NOW accounts in all six New England states, New York, and New Jersey. It has been argued that AFTs are so similar to the NOW accounts prohibited in most states by section 1832 that the statute should be read to prohibit AFTs in these states as well. ${ }^{14}$ To determine whether this statutory prohibition comprehends AFTs, it is first necessary to review the nature and structure of NOW accounts.

\section{A. NOW Accounts}

A NOW account, unlike an AFT, consists of only one account, an interest-bearing savings account. A NOW account differs from most conventional savings accounts in that the account holder can withdraw funds from the account through instruments called "negotiable orders of withdrawal." In 1972, the year in which NOW accounts were first introduced, federal banking regulations generally permitted withdrawals from savings accounts only upon presentation of a passbook or through payment to the depositor himself, ${ }^{115}$ and thus seemed to prohibit NOW accounts. But uninsured mutual savings banks in Massachusetts and New Hampshire were nevertheless able to offer the accounts because they were not at that time subject to federal interest-rate regulation. ${ }^{116}$ The Massachusetts

${ }_{112}$ Act of Aug. 16, 1973, Pub. L. No. 93-100, § 2, 87 Stat. 342 (current version at 12 U.S.C. $\S 1832$ (1976)).

113 Act of Feb. 27, 1976, Pub. L. No. 94-222, § 2, 90 Stat. 197 (Connecticut, Maine, Rhode Island, and Vermont); Financial Institutions Regulatory and Interest Rate Control Act of 1978, Pub. L. No. 95-630, $\S 1301,92$ Stat. 3712 (New York); Act of Dec. 28, 1979, Pub. L. No. 96-161, § 106, 93 Stat. 1235 (New Jersey).

"1' E.g., Consolidated Points and Authorities, supra note 3, at 36-38.

11512 C.F.R. $\$ 217.5(c)$ (1972) (current version at 12 C.F.R. $\$ 217.5(c)(1)(1979)$ ); 12 C.F.R. $\$ 329.5$ (c) (1972) (current version at 12 C.F.R. $\$ 329.5$ (c)(1) (1979)). Certain exceptions were provided for situations involving executors, administrators, court orders, and similar circumstances.

${ }^{116}$ In 1972, even state-chartered noninsured institutions were subject to federal interestrate regulation if a substantial proportion (20\%) of all deposits in the state were held in such institutions. Act of Dec. 23, 1969, Pub. L. No. 91-151, § 2(a)(1), 83 Stat. 371 (current version at 12 U.S.C. $1828(\mathrm{~g})(1976)$ ). State-chartered noninsured institutions were not subject to federal interest-rate regulation, however, if the state had its own bank-supervisory agency with rate-control authority comparable to the FDIC. Id. \& 2(a)(2), 83 Stat. 372 (repealed 1973). In 1972, only Massachusetts had such an agency. Uninsured state-chartered mutual savings banks in Massachusetts were, therefore, subject only to state interest-rate regulations even though a substantial portion of Massachusetts deposits were held in such institutions. Uninsured New Hampshire mutual savings banks were not subject to federal law, apparently because an insufficient portion of New Hampshire deposits was held in such accounts. See New Hampshire Bankers Ass'n v. Nelson, 113 N.H. 127, 302 A.2d 810 (1973); see also Riordan, supra note 111, at 154 . 
mutual savings bank that developed NOW accounts met opposition from the state banking authorities, but the highest court of the state vindicated its right to offer the service. ${ }^{117}$

Technically, the instruments used in making withdrawals from a NOW account are checks, and thus have the same legal significance as the checks written against an AFT. Under the Uniform Commercial Code (UCC), a check is any negotiable instrument drawn on a bank and payable on demand. ${ }^{118}$ The early NOW account instruments issued by the Massachusetts mutual savings banks were not only negotiable, as their name indicated, but were also drawn on banks, because the UCC definition of "bank" is sufficiently broad to include mutual savings banks. ${ }^{119}$ Furthermore, the UCC defines any instrument to be payable on demand as long as a contrary indication does not appear on its face. ${ }^{120}$ Thus, even though the mutual savings banks reserved the right to require thirty-days notice of withdrawal from their NOW accounts, the instruments they issued were payable on demand, and being also negotiable and drawn on banks, were technically checks. By these standards, instruments drawn against NOW accounts currently held at commercial banks are also checks.

Regarding a NOW account order as a demand instrument may initially appear contradictory, since the bank issuing the account against which the order is drawn may require thirty-days notice for any withdrawal. Yet, since the terms of the instrument and those of the account on which it is drawn need not be the same, the two notions are not inconsistent. The instrument is a contract between

177 Consumers Sav. Bank v. Commissioner of Banks, 361 Mass. 717, 282 N.E.2d 416 (1972). The Massachusetts Commissioner of Banks initially denied approval of NOW accounts, see Riordan, supra note 111, at 153, and the mutual savings bank seeking approval brought a declaratory-judgment action in state court seeking to reverse the Commissioner's denial. The Supreme Judicial Court of Massachusetts decided for the bank on the basis of technical language in the state savings-deposit withdrawal restrictions.

118 UCC § 3-104(2)(b). See also 12 C.F.R. § 210.2(b) (1979).

II" Under the UCC, a bank is "any person engaged in the business of banking." UCC $\S$ 1-201(4). The Code does not define "business of banking" and the scope of the phrase is not immediately apparent. See Riordan, supra note 111, at 157. One authority, in discussing this section, notes that the payment and collection functions of banks are "of vital importance to everyone" and appears to suggest that the minimal requirement an institution must fulfill to be considered "in the banking business" is the offering of payment and collection services. [1974] 5 UCC SERv. (MB) I 41.01. By this standard, even thrift institutions would seem to qualify as banks under the UCC, because they issue as drawers commercial paper payable to third-party payees for their customers and collect on instruments deposited in the accounts of their customers.

120 UCC section 3-108 provides: "Instruments payable on demand include those payable at sight or on presentation and those in which no time for payment is stated." 
the drawer of the instrument (the writer of the check) and the payee (the person to whom the check is payable). ${ }^{121}$ The account, on the other hand, is administered pursuant to a contract between the bank and the depositor, ${ }^{122}$ who, in this case, is also the person who writes the check. If, in this contract, the bank reserves the right to require thirty-days notice of withdrawal, the bank is under no obligation to pay when the check is presented. ${ }^{123}$ The depositor, on the other hand, can still promise another party (the payee) that the bank will pay upon presentment, and assume personal liability for the amount due if the bank fails to do so. ${ }^{124}$

Although the NOW accounts offered by the mutual savings banks of Massachusetts and New Hampshire are checking accounts, it is less clear that all NOW accounts are checking accounts. Under the UCC, a check must be drawn on a bank, and a bank is defined as an institution engaged in the business of banking. ${ }^{125}$ In some states, thrift institutions, such as savings and loan associations and mutual savings banks, may not be included in the definition of banks. ${ }^{26}$ NOW accounts offered by such institutions might not, therefore, be considered checking accounts. Such accounts do, nevertheless, offer customers services equivalent to checking services. The orders of withdrawal are negotiable, payable on demand, and can be used in the place of checks.

NOW accounts and AFT plans thus appear to be functionally

121 See C. Weber, Commercial Paper 2 (1975); [1976] 2 UCC Serv. (MB) $\$ 12.14$.

122 See, e.g., R. Speidei, R. Summers \& J. White, Commercial and Consumer Law 1276 77 (1974).

123 UCC section 4-103(1) delineates the ability of the bank and its customer to vary the terms of their bank-deposit contract. The only apparent limitations on this ability are that a bank cannot disclaim its responsibilities for lack of good faith or failure to exercise ordinary care, nor can it limit the measure of damages imposed as a result of such lack or failure. This appears to leave the way clear for variations arising out of the notice-option requirement. Indeed, the section provides that Federal Reserve Board regulations have the effect of agreements, and that action "pursuant to Federal Reserve regulations . . . constitutes the exercise of ordinary care." UCC $\S 4-103(3)$. Since the notice-option requirement is part of a Federal Reserve Board regulation, this language may add legitimacy to a variation in the deposit contract expressly reserving the option to require notice of withdrawal.

124 UCC section 3-413(2) imposes the secondary liability of a drawer. It provides that the drawer "engages that upon dishonor of the draft and any necessary notice of dishonor or protest he will pay the amount of the draft to the holder." See generally [1976] 2 UCC SERv. (MB) § 6.01.

125 See note 119 supra.

126 The Louisiana version of article 3 , for example, although including the UCC commercial-paper definition of "check," LA. REv. STAT. ANN. \& 10:3-104(2)(b) (West Supp. 1979), excludes the UCC definition of "bank," $i d$. § 10:1-201. Two definitions of "bank" remain in the Louisiana Code, but neither concerns commercial paper. Id. $\S \S 6: 45,9: 3801$ (1) (1951). Under these circumstances, it is not certain which definition of "bank" would control. 
equivalent-both providing combined savings services and checking services to customers. Despite this functional equivalence, the next section will demonstrate that the express language of section 1832 , although prohibiting NOW accounts outside New York, New Jersey, and New England, does not reach AFTs.

\section{B. Section 1832 and AFTs}

1. The Express Language of Section 1832. Section 1832, currently applicable in all but eight states, provides: "No depository institution shall allow the owner of a deposit or account on which interest or dividends are paid to make withdrawals by negotiable or transferable instruments for the purpose of making transfers to third parties." 127 Since NOW account depositors make withdrawals by negotiable instruments from interest-bearing savings accounts, section 1832 prohibits NOW accounts outside New England, New Jersey, and New York. AFT depositors, however, make withdrawals by conventional checks from non-interest-bearing checking accounts. An AFT incorporates two different accounts; the negotiable or transferable instrument is drawn against an account that does not bear interest, the checking account. The only withdrawal from the savings account is made by an automatic transfer, a bookkeeping entry which is neither negotiable nor transferable. The express words of the statute, therefore, do not prohibit AFTs.

The structural difference between NOW accounts and AFTs, however, has no practical impact on the services available to the bank customer. Checks drawn on AFT checking accounts still "trigger" withdrawals from interest-paying savings accounts, and the checking account is merely a conduit between the bank and payee. It can be argued, therefore, that even though the technical features of an AFT do not satisfy the statutory language of section 1832 , the formal differences should be ignored in determining the legality of AFTs. ${ }^{128}$ Yet the statute describes the prohibited accounts structurally and narrowly. Unlike section $371 \mathrm{a}$, it does not contain language prohibiting "any device whatsoever" that "directly or indirectly"129 allows banks to pay interest on an account from which withdrawals can be made by negotiable instrument. It thus appears

${ }^{127} 12$ U.S.C. $\$ 1832$ (a) (1976), as amended by Financial Institutions Regulatory and Interest Rate Control Act of 1978, Pub. L. No. 95-630, $\$ 1301$, 92 Stat. 3712, and Act of Dec. 28, 1979, Pub. L. No. 96-161, § 106, 93 Stat. 1235.

${ }^{12 s}$ See Consolidated Points and Authorities, supra note 3, at 37-38 (citing 12 U.S.C. $\S$ 1832(a) (1976)).

${ }^{129}$ See text at note 15 supra. 
initially that broad construction beyond its express terms is unjustified. Since Congress enacted section 1832 in view of specific considerations of financial regulatory policy, the scope of its application should be determined by a comparison of NOW accounts and AFTs in light of those policy objectives.

2. Policy Concerns and the Legislative History of Section 1832. When mutual savings banks in Massachusetts and New Hampshire first introduced NOW accounts, Congress considered legislative action necessary for a variety of policy reasons. Congress was concerned that NOW accounts would disturb the competitive balance between banks and thrift institutions, increase the interest rates on loans to homeowners and small businessmen, and interfere with the measurement of the money supply by the Federal Reserve Board.

a. The Competitive Balance. Banking regulation is, to a large extent, a set of delicately balanced restrictions and authorizations through which different types of depository institutions enjoy compensating advantages in the market. For example, commercial banks are the only private financial institutions to offer demand-deposit checking services. ${ }^{130}$ Although thrift institutions, such as savings and loan associations or mutual savings banks, have generally not offered such services, ${ }^{131}$ Congress has allowed these institutions to pay higher interest rates than commercial banks on time and savings deposits. ${ }^{132}$

When the mutual savings banks in Massachusetts offered NOW accounts in $1972,{ }^{133}$ this balance was disturbed. Although these institutions continued to enjoy a substantial interest-rate differential on their savings accounts over commercial banks, they were also able to attach checking services to those accounts. ${ }^{134}$ Moreover, insured commercial banks felt constrained by section $371 \mathrm{a}$ from providing comparable services, even at lower interest rates. ${ }^{135}$

130 G. KaUfMan, supra note 109 , at 61.

131 See, e.g., J. WHITE, supra note 30 , at $35,200$.

132 To aid insured savings and loan associations and mutual savings banks in securing time and savings deposits, Congress has provided them with a statutorily imposed interestrate differential to guarantee a certain competitive advantage over commercial banks. 12 U.S.C. $\S 461$ note (1976). The differential between interest rates offered by any commercial bank insured by the FDIC and any savings and loan association insured by the Federal Savings and Loan Insurance Corporation must remain constant, and cannot be altered or removed except upon written confirmation by the Federal Reserve Board to Congress and the approval of both Houses by concurrent resolution. Id.

133 See text and notes at notes 115-117 supra.

i3 See text and notes at notes 118-126 supra.

135 See, e.g., Regulation Q, NOW Accounts, Investment in State Housing Corporations: 
The apparent inequity of this situation was one of the primary reasons Congress enacted section $1832 .^{136}$

The empirical evidence available at the time Congress enacted section 1832 did not indicate that the availability of NOW accounts at mutual savings banks caused a shift in the competitive balance. ${ }^{137}$ This result is consistent with intuitive economic reasoning, which would tend to show that neither the availability of AFTs at banks nor the availability of NOW accounts at thrift institutions would cause destabilizing migration of funds from one type of institution to the other. ${ }^{138}$ The Federal Reserve Board has nevertheless con-

Hearings on H.R. 4070, H.R. 4719, and H.R. 4988 Before the Subcomm. on Bank Supervision and Insurance of the House Comm. on Banking and Currency, 93d Cong., 1st Sess. 171 (1973) (statement of Rex J. Morthland, President-Elect of the American Bankers Association).

13' See, e.g., 119 Cong. REc. 16,487-88 (1973) (remarks of Sen. Brock) ("We must deal with the question the NOW account raises, insofar as whether or not it does create a competitive disadvantage for a small commercial bank . . . . [W] cannot continue to tolerate for long a situation in which by statute there is a built-in discriminatory situation."). See also id. at 15,003 (remarks of Rep. Widnall); id. at 15,006 (remarks of Rep. Parris).

${ }_{137}$ At the 1973 Senate hearings prior to the enactment of section 1832, FDIC Chairman Wille was unable to report significant migration of funds in Massachusetts from commercial banks or savings and loan associations to mutual savings banks. Extension of Regulation $Q$ and NOW Accounts: Hearings on S. 892, S. 1008, S. 1256, and S. 1257 Before the Subcomm. on Financial Institutions of the Senate Comm. on Banking, Housing and Urban Affairs, 93d Cong., 1st Sess. 19-20 (1973) [hereinafter cited as Senate Hearings]. See also 119 CoNG. Rec. 15,007 (1973) (remarks of Rep. Frenzel) ("Testimony in committee did not indicate serious harm to competing financial institutions.").

Statistics subsequently compiled are consistent with the hypothesis that NOW accounts offered at Massachusetts and New Hampshire mutual savings banks did not precipitate a substantial drain on commercial-bank deposits during 1972 and 1973. One Federal Reserve Board study has found that on December 31, 1973, total NOW account balances in Massachusetts and New Hampshire mutual savings banks amounted to about $\$ 143.3$ million, J. Paulus, Erfects of "NOW" Accounts on Costs aNd Earnings of Commercial Banks in 1974-75, at 8 (Board of Governors of the Federal Reserve System Staff Paper 1976), which was about onethird of one percent of total commercial-bank and thrift-institution deposits in the two-state area. Id. at 12. Although total-deposit statistics are of limited value, since commercial-bank deposits include large and variable certificates of deposit, $i d$. at 14 , they are sufficiently indicative for the Federal Reserve Board staff to have incorporated total-deposit market-share statistics in evaluating the competitive effect of NOW accounts. See id. at 13. The study concluded that, in the period after Congress extended NOW account authority to most Massachusetts and New Hampshire depository institutions in 1974, competitive pressures reduced commercial-bank market shares only modestly, reflecting a market-share shift of about one percent from commercial banks to thrift institutions by the end of 1975 . Id. at 12 .

${ }_{138}$ In theory, one would not expect to find a significant migration of funds from noninterest-bearing to interest-bearing checking accounts, because banks have always paid implicit interest on checking accounts, and the payment of explicit interest represents an additional cost of the account the depositor would have to pay. When a large number of banks compete for depositors' funds, price mechanisms allocate the deposits among the banks. When banks cannot provide compensation for deposits explicitly through interest payments, they provide such compensation implicitly through services and nonmonetary rewards. Free or subsidized checking services are the primary devices used to pay interest indirectly on 
ceded the likelihood that as a result of widespread AFT authorization, a certain amount of savings-deposit balances would shift from thrift institutions to commercial banks; ${ }^{139}$ the plaintiffs in the recent AFT litigation ${ }^{140}$ alleged that the amount of funds so shifted could be as great as ten billion dollars. ${ }^{141}$ Since AFTs and NOW accounts are functionally equivalent, and since Congress enacted section 1832 in order to avoid a shift in the competitive balance, it could be argued that section 1832 must prohibit either account. ${ }^{142}$ Closer examination of the relevant issues, however, indicates that section 1832's express language should not be extended on this basis.

AFTs, unlike NOW accounts, do not introduce a fundamental change in the types of services various depository institutions can offer. The mutual savings banks offering NOW accounts in Massa-

checking accounts. See generally The IMPACT of PAYMENT, supra note 29, at 19-21. The Federal Reserve Board has estimated that banks pay implicit interest on personal checking accounts at $4.43 \%$ to $5.48 \%$ (depending on the size of the bank) by subsidizing checking services. Id. at 22. Gifts to depositors are another form of implicit interest but are limited by regulations. 12 C.F.R. $\$ \S 217.2(b), 217.147$ (1979). Other forms of implicit interest include less obvious benefits: convenient branch offices, attractive facilities, low loan rates for customers with large deposits, and subsidized financial services and programs. THE IMPACT OF PAYMENT, supra note 29 , at 23.

Since banks already pay implicit interest through subsidies on checking and other services, when they begin to pay explicit interest as well, customers stand to receive double compensation for their deposits. Banks tend to foreclose this possibility by decreasing implicit payments through the imposition of service charges on previously subsidized activity. Customers at commercial banks have complained bitterly over the increased service charges imposed on checking accounts attached to AFTs. See, e.g., Wall St. J., Dec. 6, 1978, at 1, col. 6. Banks also impose costs on AFTs through minimum-balance requirements.

Similarly, when thrift institutions introduced NOW accounts, they imposed significant per-instrument service charges or substantial minimum-balance requirements. See Senate Hearings, supra note 137, at 142. Although these institutions had been paying explicit interest on their savings accounts, they had not previously incurred the costs of maintaining checking services. Once again, the introduction of a new benefit imposed a new cost, and migration of funds was not at all as extreme as expected. See note 137 supra.

Moreover, one Federal Reserve Board study has maintained that the total of explicit and implicit returns paid to depositors on interest-bearing checking accounts would exceed present implicit interest levels only for a brief period. Thereafter, the study found that new explicit rates, combined with what was left of implicit payments, would approximate the level of the original implicit interest rate. THE IMPACT OF PAYMENT, supra note 29, at 60 . This pattern would also apply to AFTs so as to minimize the additional net return to many depositors, as banks and customers have apparently realized.

Thus, although it has been implied that AFTs are so obviously attractive that depositors would transfer funds to them en masse, see Note, supra note 90 , at 393 , such a result is unlikely and not supported by recent experience.

${ }^{139}$ Plaintiff's and Defendants' Joint Appendix at 103, American Bankers Ass'n v. Connell, 595 F.2d 887 (D.C. Cir. 1979), cert. denied 48 U.S.L.W. 3258 (U.S. Oct. 15, 1979).

110 See text and notes at notes 2-10 supra.

16 Consolidated Points and Authorities, supra note 3, at 57 n.39.

112 See, e.g., id. at 36. 
chusetts and New Hampshire were not only offering commercial bank-type transactions accounts for the first time in those states, but they were free to pay higher rates of interest on those accounts than commercial banks were allowed to pay on nontransactional accounts. ${ }^{143}$ Commercial banks have, however, traditionally offered both savings and checking accounts, the two accounts present in an AFT. The only new feature in an AFT is the savings-account withdrawal mechanism, and this mechanism is functionally similar to withdrawal methods already available. Bank customers have always been able to withdraw money from savings to cover checks. ${ }^{144}$ Originally, depositors could make such withdrawals only upon presentation of a passbook, ${ }^{145}$ but now depositors can authorize transfers by telephone. ${ }^{148}$ The only functional difference between the telephonetransfer system and an AFT is that with the latter a customer need not make a phone call in order to transfer money from savings to cover checks. Moreover, in recent years the Federal Reserve Board and the FDIC have liberalized their withdrawal restrictions to permit prearranged automatic withdrawals from savings accounts. Since 1962, regulations have permitted customers to authorize

113 See, e.g., Senate Hearings, supra note 137, at 142 (remarks of Mr. Elliot Carr). Congress has since prohibited, in New England and New York, any differential between interest paid on AFTs by commercial banks and that paid by thrift institutions. 12 U.S.C. $\$ 461$ note (1976), as amended by Financial Institutions Regulatory and Interest Rate Control Act of 1978, Pub. L. No. 95-630, § 1602(c), 92 Stat. 3713. See note 155 infra.

iu The provisions of Regulation $Q$ have never prevented a bank from allowing a savingsdeposit holder routinely to make personal transfers from savings to demand-deposit checking accounts to cover checks. Even the initial version of the regulation, adopted in 1933, required only that the account be held for "bona fide thrift purposes," that the notice option apply, that the "pass book or other form of receipt" be presented with every withdrawal, and that such limitation be included in a written contract with the depositor. 19 Fed. Res. Bull. 571, 573 (1933). The routine practice of transfer, of course, would always be subject to potential imposition of the notice requirement, as is the use of AFTs. But cf. 20 id. 389 (1934) (Federal Reserve Board emphasized that "[t]he primary purpose of the requirement that savings deposits consist of funds accumulated for bona fide thrift purposes is to prevent the payment of interest on funds . . . payable on demand," but made no reference to routine transfers as an evasion of the statute).

${ }_{145} 19$ id. 571, 573 (1933). See 21 id. 792 (1935) (Federal Reserve Board commentary that the 1933 definition of "savings deposit" required "that the passbook be presented whenever a withdrawal was made").

14 The Federal Reserve Board first authorized its telephone-transfer plan in 1975, 40 Fed. Reg. 16,831 (1975) (codified at 12 C.F.R. $\$ 217.152$ (1979)), reprinted in [1973-1978 Transfer Binder] Fed. Banking L. REP. (CCH) I 96,522, at which time the FDIC also announced its willingness to permit such arrangements, $i d$. The Federal Reserve Board maintains that the telephone "merely provides the customer with an additional method of communicating instructions regarding his account to his bank," thus implying that the practice does not "lead depositors to treat such accounts as extensions of their checking accounts." 12 C.F.R. $\S$ 217.152 (1979). 
banks in advance to transfer money automatically to make homemortgage payments, ${ }^{147}$ and more recently, the agencies have permitted automatic payment to most prespecified creditors. ${ }^{148}$ The only functional differences between these automatic-payment plans and an AFT is that in an AFT the creditors need not be specified in advance and the payment is made through the checking account; each check is equivalent to a one-time automatic-transfer authorization.

Finally, the new AFT withdrawal mechanism, like other new withdrawal mechanisms, ${ }^{149}$ is available to thrift institutions as well as banks. The Federal Reserve Board has explicitly stated that thrift institutions are free to offer AFTs in conjunction with commercial banks. ${ }^{150}$ Under such a plan, a thrift institution would arrange with its depositor to combine his thrift-institution savings account in an AFT with the depositor's commercial-bank checking aceount.

The new AFT withdrawal mechanism is, therefore, only the latest in a series of new withdrawal mechanisms available to both banks and thrift institutions and, unlike NOW accounts offered by thrift institutions, does not involve a radical change in the types of services offered by depository institutions.

Even apart from considerations of these recent developments, AFTs are unlikely to cause the substantial migration of funds Congress feared ${ }^{151}$ would occur if thrift institutions, but not banks, were allowed to offer NOW accounts at thrift-institution rates. Even though advocates for savings and loan associations have estimated that up to ten billion dollars may shift from thrift institutions to banks as a result of AFT availability, ${ }^{152}$ that amount represents a relatively small proportion of total thrift-institution liabilities. ${ }^{153}$

${ }^{37}$ In 1962, Federal Reserve Board and FDIC regulations first permitted preauthorized third-party payments from savings accounts, but only to pay interest, principal, or other charges due on a real estate loan, apparently in deference to a policy of maintaining the health of the construction industry. 26 Fed. Reg. 12,031 12,032 (1961).

148 40 Fed. Reg. 16,685, 33,198 (1975) (codified at 12 C.F.R. $\S \S 217.5$ (c)(1)(vii), 329.5(c)(1)(vi) (1979)), reprinted in [1973-1978 Transfer Binder] FED. Banking L. REP. (CCH) I 96,519.

"' Savings and loan associations, for example, may choose to offer telephone-transfer services. Points and Authorities in Support of Defendants' Motion to Dismiss, or, in the Alternative, for Summary Judgment at 28 \& app. D, United States League of Sav. Ass'ns v. Board of Governors of the Fed. Reserve Sys., 463 F. Supp. 342 (D.D.C. 1978).

iso [1978-1979 Transfer Binder] Fed. Banking L. Rep. (CCH) I] 97,432.

15 See note 136 supra.

152 See Consolidated Points and Authorities, supra note 3, at 57 n.39.

153 At the end of the first quarter of 1978 , for example, liabilities of mutual savings banks 
Furthermore, several factors suggest that any migration of funds will be minimal. First, the increased expense of AFTs requires that banks offering them increase service charges or minimum balances for customers maintaining the accounts. These added costs considerably lessen the desirability of AFTs for many depositors. ${ }^{54}$ Second, thrift institutions outside New England and New York can offer thrift-institution interest rates on any thrift-institution savings account in an AFT. ${ }^{155}$ Depositors are, therefore, likely to have the same incentive to maintain thrift-institution savings accounts irrespective of the legality of AFTs. Third, the funds deposited in an AFT savings account are more likely to be attracted from commercial-bank checking accounts since such funds are more likely to be held for transactional purposes than funds deposited in thrift institutions. ${ }^{158}$ Indeed, the legalization of AFTs, like the legalization of telephone transfers, increases the convenience of keeping funds held for transactional purposes in a thrift-institution savings account.

The advantages to banks in offering the AFT withdrawal mechanism, moreover, resemble most the advantages already available to commercial banks in offering telephone transfers from savings to checking accounts. Both involve a more convenient way to transfer funds to a commercial-bank demand deposit, and thrift institutions can offer both in conjunction with commercial-bank checking accounts.

and savings and loan associations amounted to $\$ 600,252,000,000$; ten billion dollars is less than $.61 \%$ of that total. See Fed. Res. Bull., July 1978, at A29.

154 See note 138 supra.

iss Although an early version of the Depository Institutions Deregulation Act of 1979, designed simply to legalize NOW accounts nationwide, had provided that "[t]he maximum rate of interest . . . payable by depository institutions on negotiable order of withdrawal accounts shall be uniform for all depository institutions," S. 1347, 96th Cong., 1st Sess. $\S$ 106(a) (1979), see 125 CoNG. REC. D817 (daily ed. June 21, 1979), that provision was superseded by a subsequent version that, in providing for the gradual elimination of interestrate ceilings, neglected specifically to equalize maximum interest rates on NOW accounts offered at all types of institutions, H.R. 4986, 96th Cong., 1st Sess. $§ 107$ (b)(1) (1979) (as amended by Senate), 125 Cong. Rec. S14,927 (daily ed. Oct. 23, 1979).

${ }^{156}$ In 1976, a Federal Reserve Board staff study estimated that $80 \%$ of all NOW balances were attracted from demand deposits, necessarily held with commercial banks. See J. PAuLus, supra note 137, at 9-11. Since the functional characteristics of NOW accounts and AFTs are so similar, AFT funds would probably be attracted from the same source. This is not inconsistent with the proposition that the higher cost of AFTs makes them undesirable to many deposit holders. The point is simply that of those deposit holders who are attracted to AFTs far more will be demand-deposit holders than savings-deposit holders. See also Points and Authorities in Support of Defendants' Motion to Dismiss or, in the Alternative, for Summary Judgment at 22-23, United States League of Sav. Ass'ns v. Board of Governors of the Fed. Reserve Sys., 463 F. Supp. 342, 352 (D.D.C. 1978). 
Although Congress prohibited NOW accounts partly out of concern for the institutional balance of holdings, it has not prohibited telephone transfers. Since AFTs do not involve the extreme alteration in types of services institutions offer that NOW accounts presented, and since Congress has not prohibited the withdrawal mechanism most analogous to AFTs, section 1832 should not be construed as prohibiting AFTs simply because they might be perceived as causing some shift in the competitive balance.

b. Higher Interest Rates. Congress actively debated the question of who stood to gain and lose from extension of NOW account authority. Some members were concerned that mutual savings banks offering NOW accounts would increase their interest rates on loans to homeowners and small businessmen because the expenses incurred in servicing NOW accounts are greater than the expenses incurred in servicing conventional savings accounts. ${ }^{157}$ NOW account supporters maintained that NOW accounts were desirable because they benefit the saving consumer. ${ }^{158}$ The members of Congress reached no explicit consensus as to which group was more deserving of favorable treatment: consumer-savers, such as young students and the elderly, or consumer-borrowers, such as small businessmen and young couples struggling to buy homes.

Although it is unlikely that either NOW accounts or AFTs would increase interest rates on consumer or small-business loans, ${ }^{159}$

157 Those who argue that NOW accounts are in the consumer interest, should look at the other side of the coin. It may be to some consumers' benefit to get interest on checking accounts, but it would force up borrowing costs to most other consumers who have to depend on credit. . . . But those needy persons who are struggling to own a home, or to pay a landlord's mortgage through rent, are the ones who will lose, and they are consumers too.

119 Cong. REc. 15,006 (1973) (remarks of Rep. Parris). Accord, id. at 16,488 (remarks of Sen. Brock) ("Most consumers are debtors and not creditors. If the effect of the NOW account is to raise the interest cost that all borrowers pay for consumer goods, . . . it seems to me that the definite advantage lies with the wealthy and not the poor").

ISS I have received thousands of letters from the senior citizens in my district. These people are living on fixed incomes and are desperately in need of the additional income which they can receive from the interest on these accounts. . . . It would be a great hardship for these senior citizens to have to return to regular savings accounts which would demand their presence at each transaction.

119 Cong. Rec. 15,004 (1973) (remarks of Rep. Burke). Accord, id. at 15,010 (remarks of Rep. Heckler) ("A number of those depositors are either senior citizens, or the very young, the small saver who benefits from the slightly better return that the NOW account gives him on his savings."); id. at 16,486 (remarks of Sen. Brooke) ("NOW accounts are particularly beneficial to consumers whose financial service needs are too often neglected, and who have relatively limited funds transfer needs-the young, the aged, the infirm.").

${ }^{159}$ The argument that the explicit payment of interest on checking accounts will raise costs and interest rates on loans is unsound. In the context of AFTs offered by commercial banks, depositors have always received implicit interest payments on commercial-bank 
congressional consensus that NOW accounts presented such a threat may have been sufficiently strong, and Congress may have believed the need to meet the threat was so compelling, that section 1832 should be interpreted to include AFTs. Congress's concern extended not to all borrowers, but chiefly to small businessmen, the young, and the elderly. Yet, increased rates on commercial-bank loans would have a much smaller impact on these groups than increased rates on thrift-institution loans. For example, at the end of the first quarter of 1978, thrift institutions provided over half of the outstanding mortgage money lent to farmers and owners of one- to four-family dwellings. ${ }^{160}$ Commercial banks provided less than $16 \%$ of such funds. ${ }^{161}$ In addition, a much smaller proportion of commercial-bank assets is invested in such loans, and therefore a much smaller portion of such expenses would be passed on to homeowners and small businesses. At the end of the first quarter of 1978, over half of the assets of thrift institutions were mortgages to farmers and owners of one- to four-family residences, ${ }^{162}$ but at the end of 1977 , only $19 \%$ of commercial-bank assets were so held. ${ }^{163}$

Section 1832 should not, therefore, be interpreted as prohibiting AFTs on the basis that such plans will increase the interest rates

checking accounts, and the cost to banks of explicit interest payments is unlikely to be significantly greater than costs presently incurred through implicit payments. See note 138 supra. AFTs do not tempt banks to increase lending rates since in the long run AFTs do not present significantly increased costs.

In the context of NOW accounts or AFTs offered by thrift institutions, the increased costs arise not out of the expense of paying interest, which thrift institutions have always paid, but out of the expense of providing checking services, which they have not previously provided. It is unlikely, however, that borrowers would pay additional costs as a result of the checking accounts offered depositors. The costs of these checking services would, in the long run, represent no net additional costs to thrift institutions; the provision of the services is merely an alternate form of an additional return that thrift institutions have previously absorbed through the offering of free gifts, the maintaining of many branch offices, or through other forms of implicit interest commonly paid by commercial banks. See THE IMPACT of PAYMent, supra note 29, at 60-71. There may even be evidence that during the early NOW account period in Massachusetts, the offering of NOW accounts improved mortgage lending conditions. See 119 Cong. REc. 16,487 (1973) (remarks of Sen. Brooke).

100 Fed. Res. Bull., July 1978, at A41. Farm mortgages and mortgages taken out by owners of one- to four-family dwellings amounted to over $\$ 739$ billion, but holdings of such mortgages at mutual savings banks and savings and loan associations amounted to over $\$ 378$ billion.

111 Id. Commercial-bank holdings of such mortgages amounted to less than $\$ 113$ billion.

162 Id. at A29. The total assets of savings and loan associations and mutual savings banks for this period was over $\$ 626$ billion, as compared with the $\$ 378$ billion figure for mortgage holdings set forth in note 160 supra.

is Id. at A18, A41. By the end of the year, total commercial-bank assets were over $\$ 1,166$ billion, compared with slightly less than $\$ 110$ billion of holdings of farm and one- to fourfamily dwelling unit mortgages for the same period. 
on commercial-bank loans. There was no consensus in Congress that NOW accounts should be prohibited for this reason, and AFTs will affect interest rates on loans to homeowners and small businesses to a much smaller extent than NOW accounts. Indeed, any other conclusion would entail the assumption that the enacting Congress favored commercial borrowers over consumer-savers in an attempt to maintain existing lending rates for the former by limiting interest income to the latter.

c. Measuring the Money Supply. The final major objection to NOW accounts voiced in the congressional debates was that these accounts would decrease the accuracy of the Federal Reserve Board's monetary measurements. The Federal Reserve measures the money supply in several different ways and uses these measurements to determine whether the money supply should be increased or decreased. The narrowest measure of the money supply combines currency plus most demand deposits at commercial banks. ${ }^{164}$ Only the broader measures of the money supply include time and savings deposits. ${ }^{165}$

The aggregate measurements distinguish between demand deposits and other types of deposits because most depositors hold demand-deposit funds for transactional purposes and those funds therefore most nearly resemble currency, ${ }^{166}$ whereas depositors usually hold savings and time deposits for nontransactional purposes. This method of measuring the money supply is disturbed if depositors shift funds held for transactional purposes from demand deposits to savings accounts. ${ }^{167}$ Upon opening a NOW account (or an AFT), a depositor would generally make this shift. Congress feared that monetary policymakers would thus observe a decline in demand deposits and increase the money supply when the money supply had actually remained constant, ${ }^{168}$ inadvertently worsening inflation. ${ }^{169}$

184 See, e.g., id. (Dec. 1978) at A3 1..1.

iss Id. As this issue went to press, the Federal Reserve Board had recently instituted a new system of money supply measurements, see N.Y. Times, Feb. $8,1980, \S \mathrm{D}$, at 1, col. 3, which nevertheless retains the basic distinction between demand deposits and time and savings deposits.

its See R. KENT, supra note 68, at 5.

${ }^{167}$ See Wall St. J., Feb. 21, 1979, at 8, col. 2 (remarks of Mark Willes, President of the Federal Reserve Bank of Minneapolis).

168 See NOW Accounts, Regulation Q, and Investment in State Housing Corporations: Hearings on H.R. 4070, H.R. 4719, and H.R. 4988 Before the Subcomm. on Bank Supervision and Insurance of the House Comm. on Banking and Currency, 93d Cong., 1st Sess. 13 (1973).

189 The monetary distinction between demand deposits and savings accounts is to a certain extent unjustified. Through telephone-transfer and bill-payer plans, depositors already use funds in savings accounts for transactional purposes. In addition, since the notice 
The Massachusetts and New Hampshire NOW accounts were not, however, legalized by the Federal Reserve Board; they were offered by institutions subject only to state law. ${ }^{170}$ Thus, the Federal Reserve Board could not prohibit these accounts if they interfered with money-supply measurement. Only congressional action could eliminate the potentially destructive effect of these accounts on monetary measurements. Such is not the case with AFTs.

The Federal Reserve Board authorized AFTs and can limit or prohibit them if they should later disrupt monetary measurement. Moreover, the methods used by the Federal Reserve Board to measure the money supply are determined solely by the Board. ${ }^{171}$ The Federal Reserve Board has, in the past, authorized other methods of withdrawal from savings accounts that blur the distinction between money held for transactional and nontransactional purposes, such as telephone-transfer and automatic bill-payer plans. ${ }^{172} \mathrm{Nei}$ ther Congress nor the judiciary has struck down either of these withdrawal methods. Given the degree of control of the Federal Reserve Board over AFT authorization, and given previous regulatory authorizations of similar plans, AFTs do not present the same degree of uncertainty or uncontrollability that NOW accounts arguably presented in 1973 .

d. Intended Scope of Section 1832. When Congress enacted section 1832, it did not address the broad question of payment of interest on checking accounts. Section 1832 was a specific response to the NOW accounts offered by Massachusetts and New Hampshire mutual savings banks. The dominant attitude of Congress in enacting section 1832 was tentative and experimental. One representative indicated that Congress designed section 1832 so that its members could "wait-and-see"173 what the results of NOW accounts

option for savings deposits is never exercised, depositors often rely on and use savings-deposit funds for transactional purposes even when withdrawls cannot be made by telephone or automatically. See Commission on Financial Structure and Regulation, supra note 30, at 28.

17 See text and notes at notes 115-117 supra.

17 Indeed, the Federal Reserve Board's new system of monetary measurement, supra note 165 , implicitly recognizes the transactional character of NOW accounts and AFTs. Experience thus demonstrates the Federal Reserve Board's ability to deal with new types of accounts through monetary redefinition. Even before inauguration of the new system, however, the total control of the Federal Reserve Board over AFT authorization sufficiently distinguished AFTs from NOW accounts for the purposes of the monetary-measurement policies of the 1973 NOW account prohibition.

172 See text and notes at notes 146-148 supra.

is 119 Cong. Rec. 15,003 (1973) (remarks of Rep. Widnall). See also id. at 16,491 (remarks of Sen. Bennett) ("My interest in this thing is not to kill the NOW accounts. My interest is to keep the fire under control until we can have time to determine the best way in which we can allow it to spread across the country."). 
would be on a limited scale; passage of the statute did not indicate congressional favor of an absolute and permanent prohibition of NOW accounts. ${ }^{174}$ Indeed, section 1832 preserved the status quo outside Massachusetts and New Hampshire by prohibiting NOW accounts in other states.

When Congress enacted section 1832 , it did not modify section 371 's prohibition against the payment of interest on demand deposits. Instead, Congress prohibited the payment of interest on one additional kind of account-NOW accounts. The express language of section 1832 cannot be extended to prohibit AFT plans without extending the scope of the statute beyond that intended by Congress.

\section{CONCLUSION}

Since 1933, federal law has prevented commercial banks from paying interest on demand deposits, and has thus prohibited interest payments on the type of checking account most depositors hold. In recent years, depository institutions and regulatory agencies have devised various services that approximate interest-paying demand deposits while purportedly avoiding violation of the 1933 prohibition. The legality of the AFT, the latest in this series of innovations, rests in part on the validity of a set of bank-deposit definitions promulgated by the Federal Reserve Board and the FDIC. The definitions exclude AFTs from the category of demand deposits, and thus ensure the legality of AFTs provided that the definitions are consistent with the congressional purposes of the 1933 statute. Historical analysis reveals that these definitions, although remote from the popular conceptions of the deposits they describe, have a strong foundation in the economic precepts of the original legislation, and are completely consistent with the purposes of the statute. AFTs are

17 The first version of the section 1832 legislation passed by the House, H.R. 6370, 93d Cong., 1st Sess. (1973), 119 CoNG. REc. 15,008 (1973), contained an absolute prohibition of NOW accounts in all states. The original version of the Senate bill, S. 1008, 93d Cong., 1st Sess. (1973), would have expressly permitted all NOW accounts. The bill passed by the Senate, S. 1798, 93d Cong., 1st Sess. (1973), occupied a middle ground between this blanket authorization and the absolute prohibition of the House bill, permitting the accounts to continue in Massachusetts and New Hampshire but prohibiting them in the other states. 119 ConG. REc. 16,485 (1973). The Senate version also allowed all "depository institutions" to offer the accounts, whereas even the more liberal of the House bills allowed only mutual savings banks to offer NOWs. The Senate sent its version to the House and a conference was necessary to resolve the issue, 119 CoNG. REC. 16,502-03 (1973). The conference essentially adopted the Senate version, but eliminated credit unions from the list of defined depository institutions. Id. at 28,020 . 
thus legal under both the letter and spirit of the prohibition of interest payments on demand deposits.

Recent federal legislation prohibiting depository institutions from offering NOW accounts poses a second threat to the legality of AFTs. AFTs are functionally equivalent to NOW accounts, and opponents of AFTs argue that the 1973 Act thus prohibits AFTs by implication. The explicit terms of the statute, however, do not address AFTs; the statute was adopted solely to halt the proliferation of NOW accounts. Furthermore, the policy considerations responsible for the NOW account legislation apply with considerably lesser force to AFTs.

Neither the section 371a prohibition nor the NOW account legislation properly should be read to comprehend AFTs. Accordingly, legislation now pending in Congress explicitly legalizing AFTs is unnecessary to legitimate their use.*

Tony S. Winer

* After this issue went to press, President Carter approved the Depository Institutions Deregulation and Monetary Control Act of 1980, Pub. L. No. 96-221, 94 Stat. 132, which initiated wide-ranging changes in federal banking regulation. The Act has the effect of permanently authorizing federally insured commercial banks to offer AFTs. Although the legality of AFTs thus no longer depends on construction of the statutes and regulations examined by this comment, the thesis of the comment-that AFTs were legal in terms of the regulatory framework under which they developedstill remains valid. Moreover, the historical analyses presented still provide a useful background for analogous issues relating to those parts of the earlier statutes and regulations still in effect. 